\title{
Anthropogenic and forest fire pollution aerosol transported to the Arctic: observations from the POLARCAT-France spring campaign
}

\author{
B. Quennehen ${ }^{1,4}$, A. Schwarzenboeck ${ }^{1}$, A. Matsuki ${ }^{2}$, J. F. Burkhart ${ }^{3}$, A. Stohl ${ }^{3}$, G. Ancellet ${ }^{4}$, and K. S. Law \\ ${ }^{1}$ Laboratoire de Météorologie Physique, UMR6016, Université Blaise Pascal, CNRS, Aubière, France \\ ${ }^{2}$ Frontier Science Organization, Kanazawa University, Japan \\ ${ }^{3}$ Norwegian Institute for Air Reasearch (NILU), Kjeller, Norway \\ ${ }^{4}$ UPMC Univ. Paris 06; Université Versailles St-Quentin; CNRS/INSU, LATMOS-IPSL, UMR8190, Paris, France
}

Correspondence to: B. Quennehen (b.quennehen@opgc.univ-bpclermont.fr)

Received: 23 January 2012 - Published in Atmos. Chem. Phys. Discuss.: 8 February 2012

Revised: 26 June 2012 - Accepted: 26 June 2012 - Published: 24 July 2012

\begin{abstract}
During the POLARCAT-France airborne measurement campaign in spring 2008, several pollution plumes transported from mid-latitude regions were encountered. The study presented here focuses on air masses from two different geographic origins (Europe and Asia) and from 2 different source types (anthropogenic pollution and forest fires). A first case study is dedicated to a European air mass, which was repeatedly sampled and analysed during three consecutive days. Thereby, the evolution of the aerosol properties (size distributions, $\mathrm{CO}$ mixing ratio) is characterised and related processes are discussed. In particular, the role of coagulation, condensation and cloud processing in the evolution of the Aitken and the accumulation mode particles are contrasted.

A second case study focuses on European air masses impacted solely by biomass burning emissions and Asian air masses with contributions from both biomass burning and anthropogenic emissions. The analysis of aerosol modes highlight a similar behaviour for particle originating from biomass burning (from Europe as well as Asia). In comparison to the predominating aged accumulation mode in biomass burning particles, a still larger aerosol accumulation mode related to Asian anthropogenic emissions can be isolated. These findings corroborate the external mixing of such kind of aerosol size distributions. An electron microscopy study (coupled to X-ray elemental analysis) of particles illustrated soot-like inclusions in several samples. Within samples attributed to forest fire sources, the chemical signature is highly associated with the presence of potassium, which is a characteristic tracer element for biomass burning plumes.
\end{abstract}

The single particle images suggest an internal mixing of sampled individual aerosol particles. Thus, particles are found externally mixed as demonstrated from particle size distributions while they appear internally mixed at the particle scale.

\section{Introduction}

Since the polar regions are more sensitive to global change than others (IPCC, 2007), a better understanding of the polar climate system is fundamental. This is why an increasing number of studies in the Arctic are dedicated to the collection of measurement data in order to improve our current understanding on climate related processes in the Arctic atmosphere (Law and Stohl, 2007). While ground-based observations have been regularly performed at a few existing measurement stations (e.g., Sharma et al., 2002, 2004, 2006 and Quinn et al., 2002, 2007), aircraft observations of the Arctic atmosphere remain rare.

Aerosol particles play an important role in the global climate (IPCC, 2007) through their direct (McCormick and Ludwig, 1967) and indirect effects (Twomey, 1977; Albrecht, 1989) on Earth's radiative budget. These effects remain poorly investigated in the Arctic regions and are difficult to quantify, implying large uncertainties (Garrett and Zhao, 2006; Lubin and Vogelmann, 2006). Since few pollution sources exist in the Arctic regions (e.g., the Kola peninsula as shown by Frossard et al., 2011 and Merlaud et al., 2011), polluted air masses observed in the Arctic are mainly transported from mid-latitude regions, leading for example 
to the build up of Arctic Haze, firstly observed by pilots flying over Arctic regions (Greenaway, 1950; Mitchell, 1957), more recently the phenomenon has been discussed with respect to its spatial extent by Dreiling and Friederich (1997), and summarised by Quinn et al. (2007). Arctic Haze studies were mainly conducted to investigate the chemical and optical properties of Arctic Haze aerosol particles (Schnell, 1984; Clarke et al., 1984; Brock et al., 1990). Arctic Haze is mainly composed of particulate organic matter and sulphate and, to a lower extent, black carbon (Quinn et al., 2002). Arctic Haze originates from biomass burning and/or anthropogenic sources from any continent in the Northern Hemisphere. Eurasia (including Europe, former USSR countries, Siberia and northern China) is considered to be the major source region for Arctic Haze, particularly observed during the winter and early spring seasons (Stohl, 2006; Sharma et al., 2004, 2006; Hirdman et al., 2010; Huang et al., 2010; Brock et al., 2011).

However, aerosol characteristics in the Arctic are different from over source regions. This is due to ageing and/or removal processes which occur during transport of the pollution plume from its sources to the Arctic. The principal transformation processes are listed below:

- Coagulation: describes the process of a particle colliding with another one, thus, forming one larger particle. As a consequence coagulation is reducing the total particle number concentration at a rate proportional to the square of particle concentration (Hinds, 1999). A broad particle size distribution can be rather effective in scavenging the smallest particles.

- Condensation: this process corresponds to the growth of particles by condensation of the gas phase on particles (Hinds, 1999). Main condensable gases are depending on the pollution sources.

- Cloud processing: a part of the aerosol population is activated as cloud condensation nuclei and subsequently chemically transformed in the liquid phase (Seinfeld and Pandis, 1998).

- Dilution/mixing: by mixing surrounding air into a highly concentrated pollution plume, aerosol number and mass concentrations are reduced.

In addition, during their lifecycle, aerosols are subject to various removal processes:

- Dry deposition, which is most efficient for coarse mode particles (Seinfeld and Pandis, 1998).

- Wet deposition, which affects mostly accumulation mode particles. It corresponds to the in-cloud scavenging (washout) and below-cloud scavenging (rainout) (Seinfeld and Pandis, 1998).
Whereas transformation of anthropogenic pollution aerosol is strongly related to both condensation and coagulation processes (Riemer et al., 2004), the transformation of biomass burning aerosol particles ageing is predominantly explained by the coagulation process at least in the far field of the source region (Fiebig et al., 2003; Dentener et al., 2006; Petzold et al., 2007; Müller et al., 2007).

In this context, and within the frame of the 4th International Polar Year (IPY, 2007-2008), the POLARCAT (POLar study using Aircraft, Remote sensing, surface measurements and models, of Climate, chemistry, Aerosols and Transport) project was launched. The objectives within POLARCAT are particularly focusing on improving our knowledge related to long-range transport of short-lived pollutants (particulates and gases) to the Arctic. The approach chosen for POLARCAT has been to combine aircraft (in situ and remote-sensing) measurements with extensive model studies. Within the French contribution to the POLARCAT project, the French ATR-42 research aircraft was deployed out of Kiruna, Sweden in April 2008 and out of Kangerlussuaq, Greenland in July 2008. It performed 24 scientific flights with state of the art instrumentation measuring physical and optical aerosol properties. While for the summer campaign, studies have been presented recently (Schmale et al., 2011; Quennehen et al., 2011), this work focuses on the spring aerosol measurements. Most recently, Adam de Villiers et al. (2010) and Merlaud et al. (2011) presented results from the spring measurements of aerosol optical properties and $\mathrm{NO}_{2}$ distributions, respectively.

The main objective of the study presented here is to investigate the physical properties of pollution aerosol particles transported to the Arctic demonstrating particularly aerosol ageing observed from measurement data during the campaign. In the following, after a short presentation of the measurement instrumentation, the paper focuses on two case studies, presented in separate sections three and four. The first case study is related to an European anthropogenic polluted air mass sampled during three consecutive days, in order to study transformation of aerosol particles within pollution plumes transported to the Arctic. The transformation is particularly seen in the Aitken mode. The second case study focuses on Eurasian polluted air masses, including Russian and Siberian forest fires, as well as an Asian anthropogenic plume.

\section{Instrumentation on board the ATR-42 French aircraft and analysis of air mass origins}

\subsection{Instrumentation}

\subsubsection{Aerosol physical properties}

Since the POLARCAT spring campaign was dedicated to cloud studies, a CVI (Counterflow Virtual Impactor, 
Schwarzenboeck et al., 2000) inlet was operated on the ATR42. The CVI inlet is equipped with a backward facing interstitial inlet and can also be operated isokinetically for total aerosol sampling in clear sky conditions. For isokinetic sampling, the counterflow was switched off, and the controlled flow is increased to meet measured air speed in the shroud. Downstream the inlet, clear sky aerosol size distributions were measured by the combination of a Scanning Mobility Particle Sizer (SMPS, Villani et al., 2008) and an Optical Particle Counter (OPC, Grimm model 1.108), both operated inside the ATR-42 cabin. While the SMPS measured particle number size distributions in the range $20<D_{\mathrm{p}}<500 \mathrm{~nm}$, where $D_{\mathrm{p}}$ is the particle diameter, the OPC sized particles with diameters in the range $300<D_{\mathrm{p}}<2000 \mathrm{~nm}$. The number concentrations derived from SMPS plus OPC are compared with total concentration from a Condensation Particle Counter (CPC 3010, TSI), which measured particles with diameter greater than $10 \mathrm{~nm}$. In the overlap region, only SMPS measurements were considered. In general, the comparisons between OPC and SMPS concentrations in the overlap region reveals good agreement.

In addition, the aerosol particle volatility was measured with a second set of SMPS and OPC instruments heated up to $280^{\circ} \mathrm{C}$ using a thermo-denuder located upstream the second set of SMPS and OPC. After the thermal conditioning, refractory particles are supposed to be mainly composed of soot, sea salt, mineral dust and some refractory fraction of organic carbon. Ambient and $280^{\circ} \mathrm{C}$ particle volume concentrations were calculated and used in order to determine the aerosol volatile fraction:

$F_{\text {volatile }}=\frac{V_{\text {ambient }}-V_{280}{ }^{\circ} \mathrm{C}}{V_{\text {ambient }}}$

$F_{\text {volatile }}$ represents the volume fraction of particulate matter volatilised after heating. The volatile volume fraction of solely accumulation mode particles $F_{\text {volatile, ac }}$ is calculated in the following way:

$F_{\text {volatile, ac }}=\frac{V_{\text {ambient, ac }}-V_{280}{ }^{\circ} \mathrm{C}, \mathrm{ac}(\mathrm{ref})}{V_{\text {ambient,ac }}}$

Where $V_{\text {ambient,ac }}$ is the aerosol accumulation mode volume

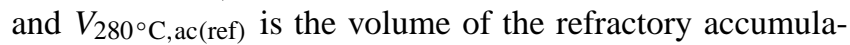
tion mode. Finally, the number fraction of solely accumulation mode volatile particles $\left(F_{\text {conc,ac }}\right)$ is calculated accordingly:

$F_{\text {conc }, \text { ac }}=\frac{N_{280^{\circ} \mathrm{C}, \mathrm{ac}(\mathrm{ref})}}{N_{\text {ambient }, \mathrm{ac}}}$

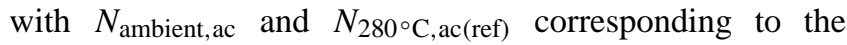
aerosol accumulation mode concentration at ambient temperature and at $280^{\circ} \mathrm{C}$, respectively. The measurement efficiencies of both SMPS/OPC systems were inter-compared regularly during the campaign, usually before take-off and without thermo-desorption. Deviations between both systems were found to be below the instrument uncertainties (Quennehen et al., 2011).

\subsubsection{Aerosol chemical properties and trace gas concentrations}

The chemical composition of aerosol particles was investigated using aerosol samples collected by a two-stage impactor. The impactor type used in this study is identical to that described in Matsuki et al. (2005a,b). The $50 \%$ cut-off aerodynamic diameters are 1.6 and $0.2 \mu \mathrm{m}$ for the first and second stage, respectively, with a volume flow rate of approximately $1.01 \mathrm{~min}^{-1}(1013 \mathrm{hPa}, 293 \mathrm{~K})$. Thus, in practice, supermicron particles are found in the first stage of the impactor while submicron particles impact during the second stage. The decision to start or stop sampling was made in situ by the on-board operator according to the circumstances (i.e., by taking into account the flight patterns and spatial extent of pollution plumes/cloud samplings during respective flights). The aim of the individual particle analysis within the spring campaign was to study both pollution aerosol particles from clear sky samples and residual particles from liquid/ice phase Arctic cloud samples. The frequency and duration of the individual samples taken during the flights were a function of the flight patterns and spatial extent of pollution plumes/cloud samplings during respective flights. More information about the sampling substrate of the impactor is given in Matsuki et al. (2010).

In situ samples were then analysed in the laboratory after the flights. Submicron samples were imaged utilising a transmission electron microscope (TEM, JEM-2010FEF, JEOL) to obtain high resolution images. Furthermore, an Energy Dispersion X-ray spectrometer (EDX, JED-2300, JEOL) monitored X-ray spectra to obtain elemental composition of individual particles. Supermicron particles were analysed by a Scanning Electron Microscope (SEM, S-3000N, Hitachi) coupled to an other EDX (EMAX-500, Horiba). The relative atomic ratios (\%) of the detected elements were quantified by the manufacturer's software in standard-less mode. Due to the limitation of the method related to the quantification of lighter elements contained in a single particle, $\mathrm{C}$, $\mathrm{N}$, and $\mathrm{O}$ were excluded from the quantitative analysis. For each sample of the submicron particles, 30 randomly chosen particles were analysed while for supermicron samples, every single particle was analysed. The number of analysed supermicron particles ranged from 16 to more than 50, depending on the particle loading of individual filters.

Carbon monoxide (CO, also investigated by Adam de Villiers et al., 2010) was measured by the MOZART CO instrument, based on the gas filtered correlation principle of infrared absorption by the $4.67 \mu \mathrm{m}$ fundamental vibrationrotation band of CO (Nédélec et al., 2003). CO is a rather inert tracer over a timescale of 10-20 days and is emitted by combustion processes (both biomass burning and anthropogenic combustion). In this study, excess $\mathrm{CO}$ is used instead of total $\mathrm{CO}$ mixing ratio. Excess $\mathrm{CO}$ is obtained by subtracting the background value of $120 \mathrm{ppbv}$ (Pommier et al., 2010) from the total CO mixing ratio. 


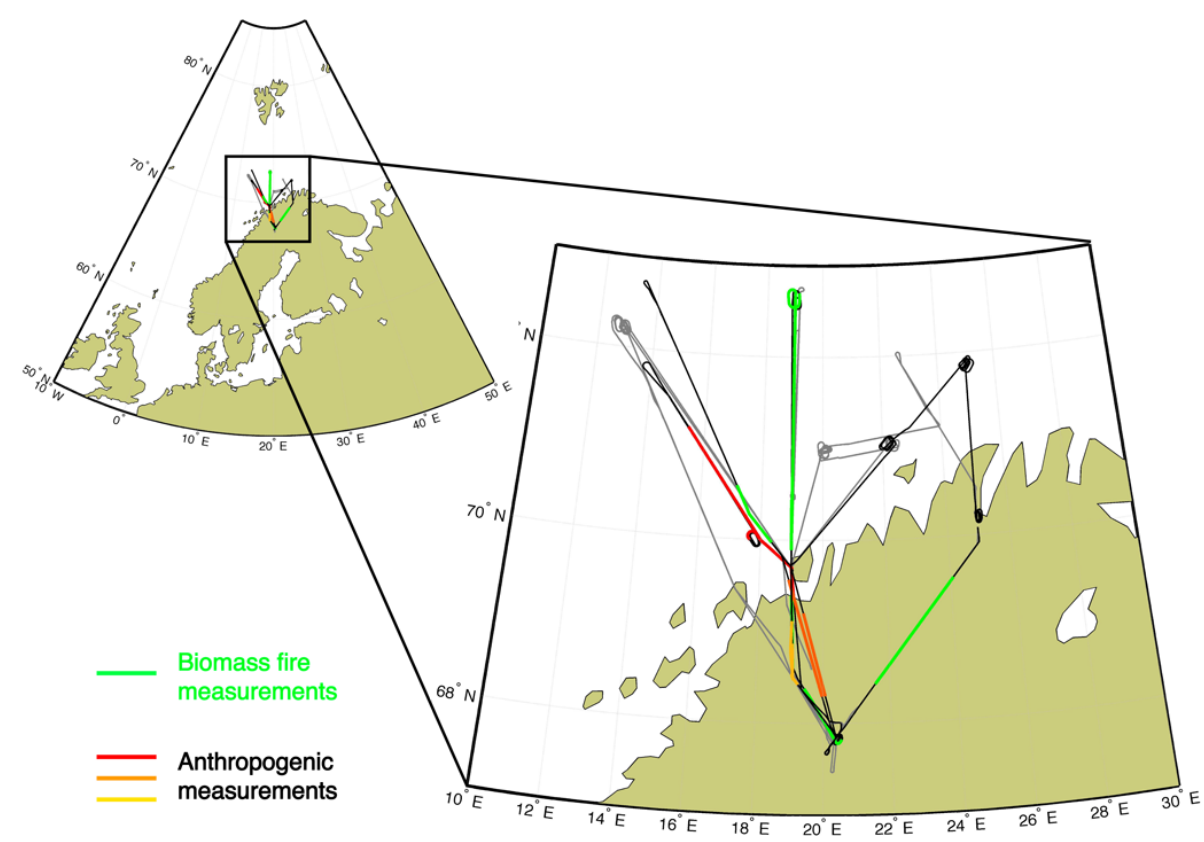

Fig. 1. ATR-42 flight tracks highlighting the legs on which forest fire and anthropogenic plumes were sampled.

Additionally, $\mathrm{NO}_{2}$ measurements were performed using an Airbone Limb Scanning-Differential Optical Absorption Spectrometer (ALS-DOAS) as presented in Merlaud et al. (2011).

\subsection{Air mass origins and ages}

In order to derive the origins of air masses sampled during the POLARCAT-France spring campaign, the FLEXPART Lagrangian particle dispersion model (version 6.2) (Stohl et al., 1998, 2005) was used in its backward mode (Stohl et al., 2003). The model was repeatedly initialised along the flight trajectories for aircraft position changes of more than $0.20^{\circ}$ in horizontal dimension and/or $150 \mathrm{~m}$ in vertical dimension. For every single run, 40000 particles were released from a small volume around the aircraft position and then were tracked during twenty days (backwards in time). The primary output of FLEXPART backward calculations is the potential emission sensitivity (PES), column-integrated values of which were used here mainly to characterise the origin and transport pathways of the sampled air masses. Footprint potential emission sensitivities (FPES) correspond to the PES values of the lowest layer in the model output $(0-100 \mathrm{~m})$. Since pollutant emissions mostly occur at the Earth's surface, FPES provide important information about the potential sources of pollution for the sampled air masses. In addition to PES and FPES, hot spots detected by the radiospectrometer MODIS (Giglio et al., 2003) are indicated in red and black illustrating forest fires and other fires (e.g., agricultural), respectively.
As mentioned above, each flight segment (aircraft position changes of more than $0.20^{\circ}$ in horizontal dimension and/or $150 \mathrm{~m}$ in vertical dimension) along the aircraft trajectory is considered as a starting point by FLEXPART. For each flight segment 40000 particles were released by the model and at each time step (up to 20 days) the position of every single particle is calculated. Thus, when a particle reaches the ground (or the lower vertical layer of the model for the biomass burning areas), the particle age is obtained. For the 40000 particles per segment, an age spectrum ranging from one to twenty days is derived. The integration of this age spectrum leads to the estimation of a mean plume age called hereafter FLEXPART age.

\subsection{Lagrangian matches with FLEXPART}

Following the approach outlined in Methven et al. (2006) we used FLEXTRA trajectory code to identify flight periods having a Lagrangian connection with prior flights. In addition to the latitudinal and equivalent potential temperature screening employed in the previous work, we used information on air mass longitude, elevation and $\mathrm{CO}$ concentrations to define our match information. For further details regarding the trajectory model set up and tracers used, the reader is referred to the original Methven et al. (2006) manuscript for details of the method.

For this experiment FLEXTRA was run forward for all 51 POLARCAT Spring and Summer flights. This included all flights from the NASA ARCTAS (Fuelberg et al., 2010), DLR Falcon (Roiger et al., 2011) and French ATR research 
Table 1. Criteria for the Lagrangian matches selection and identification.

\begin{tabular}{lr}
\hline Criteria & Value \\
\hline Horizontal separation & $<100 \mathrm{~km}$ \\
Minimum elevation & $250 \mathrm{~m}$ \\
Time separation & $<45 \mathrm{~min}$ \\
Elevation separation & $<1 \mathrm{~km}$ \\
Equivalent potential temperature & $<5^{\circ} \mathrm{C}$ \\
\hline
\end{tabular}

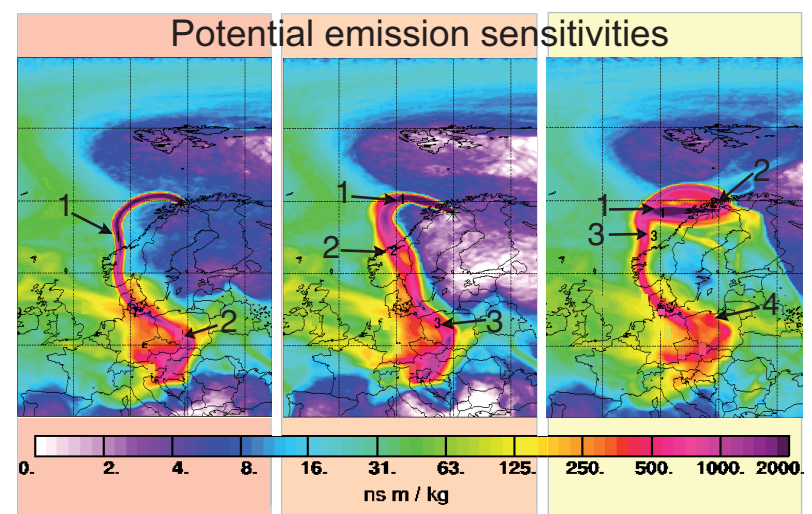

Footprint emission sensitivities

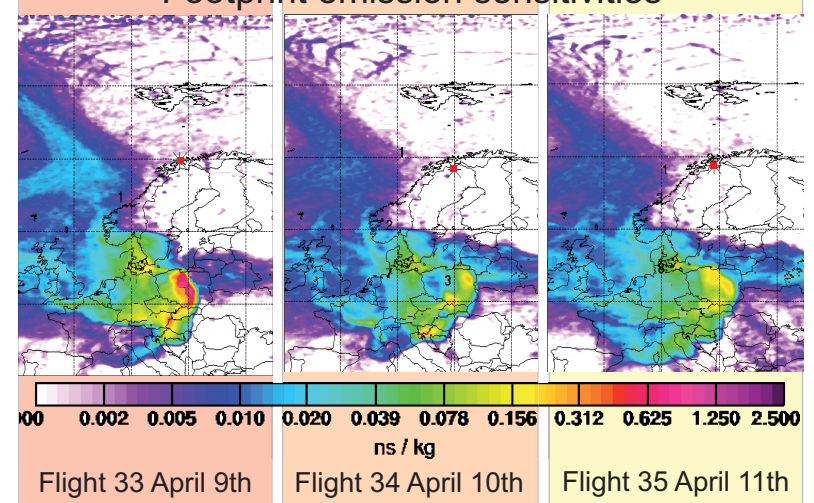

Fig. 2. FLEXPART column-integrated potential emission sensitivities (PES, top) and footprint emission sensitivities (FPES, bottom) for the anthropogenic air mass sampled during the flights on 9, 10 and 11 April 2008. Numbers indicate the air mass age in days at the location pointed by corresponding black arrows. On FES maps, red squares indicate the aircraft location, used as a starting point to run FLEXPART.

campaigns. Lagrangian matchpoints were initially selected and identified based on criteria as shown in Table 1.

In all thousands of match points were identified due to repeat trajectories for flight pairs. Furthermore, the method will generate a many-to-many relationship between flights due to the frequency of trajectories being released (10 s). Rather than choosing a "best match trajectories" approach that is representative of an ensemble of trajectories, $\mathrm{CO}$ information from the flights was used to identify the optimal trajectories of interest for analysis of biomass burning events. $\mathrm{CO}$ as a

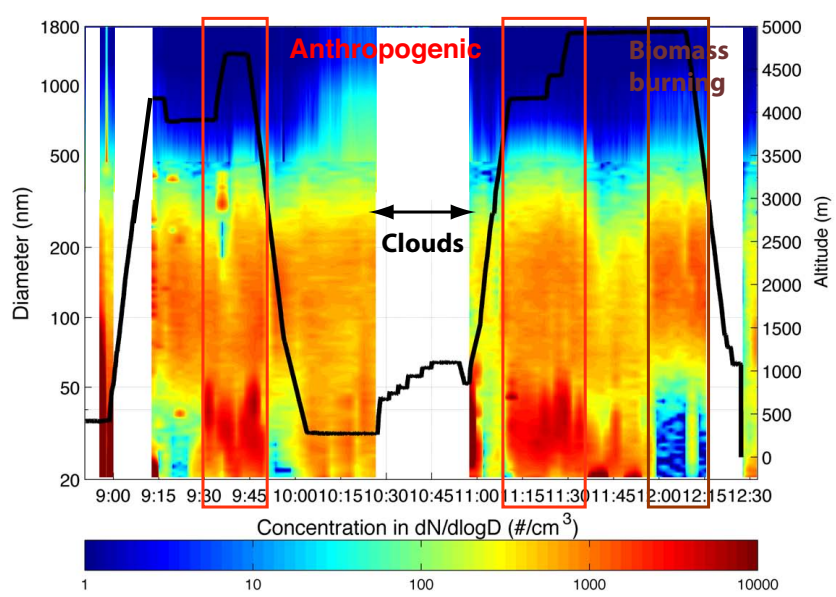

Fig. 3. Evolution of the aerosol size distribution along the flight on 9 April. While the principal y-axis (left) shows the diameter related to the colour-coded concentrations, the secondary y-axis (right) corresponds to the flight altitude plotted in black. Sampling periods related to anthropogenic and forest fire plumes are indicated with red and brown rectangles, respectively.

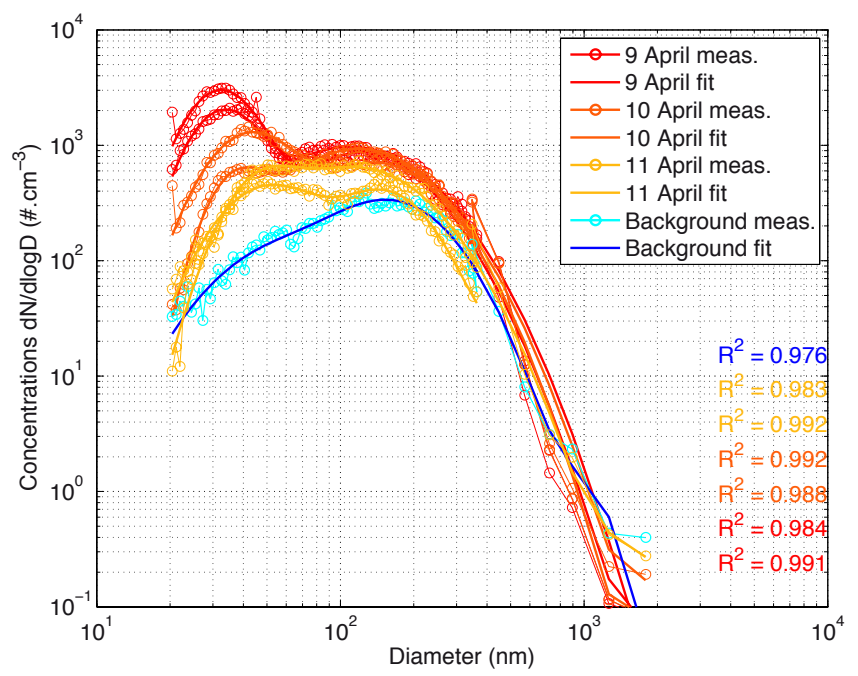

Fig. 4. Anthropogenic aerosol size distributions measured (thin solid line with circles) and fitted (thick solid line) for flights on April 9, 10 and 11 coloured in red, orange and yellow, respectively. A typical background size distribution encountered in non polluted air masses is shown in blue. Distributions are fitted with a 3 log-normal parameterisation, corresponding correlation factors are indicated.

tracer provides a good method for determining when the aircraft was sampling periods of intense biomass burning and it has a lifetime significantly longer than the period between flights. 
Table 2. Parameterisation of log-normally fitted size distributions for the anthropogenic plume. FLEXPART determined air mass ages are also indicated.

\begin{tabular}{lc|ccc|cccc|ccc|c}
\hline \multirow{2}{*}{ Flight date } & $\begin{array}{c}\text { Flexpart age } \\
\text { (days) }\end{array}$ & \multicolumn{3}{|c|}{ Aitken mode } & \multicolumn{3}{|c|}{ Accumulation mode } & \multicolumn{4}{c}{ Coarse mode } \\
& $n_{1}\left(\mathrm{~cm}^{-3}\right)$ & $\sigma_{1}$ & $d_{\mathrm{m} 1}(\mathrm{~nm})$ & $n_{2}\left(\mathrm{~cm}^{-3}\right)$ & $\sigma_{2}$ & $d_{\mathrm{m} 2}(\mathrm{~nm})$ & $n_{3}\left(\mathrm{~cm}^{-3}\right)$ & $\sigma_{3}$ & $d_{\mathrm{m} 3}(\mathrm{~nm})$ \\
\hline \multirow{2}{*}{9 April } & 4.7 & 621 & 1.35 & 33.1 & 621 & 1.80 & 108.8 & 0.018 & 1.30 & 2000 \\
& 5.3 & 981 & 1.36 & 32.2 & 556 & 1.80 & 124.8 & 0.001 & 1.30 & 2000 \\
\hline \multirow{2}{*}{10 April } & 6.7 & 132 & 1.29 & 38.2 & 595 & 1.80 & 118.5 & 0.046 & 1.30 & 2000 \\
& 7.1 & 495 & 1.44 & 42.7 & 402 & 1.69 & 139.4 & 0.024 & 1.30 & 2000 \\
\hline \multirow{2}{*}{11 April } & 7.6 & 139 & 1.36 & 48.4 & 407 & 1.79 & 116.5 & 0.102 & 1.32 & 1462 \\
& 7.8 & 210 & 1.54 & 51.9 & 163 & 1.47 & 151.0 & 20.00 & 2.00 & 800 \\
\hline \multirow{2}{*}{ Background } & & 84.8 & 1.80 & 61.2 & 157.7 & 1.62 & 165.6 & 0.303 & 1.30 & 941 \\
\hline
\end{tabular}

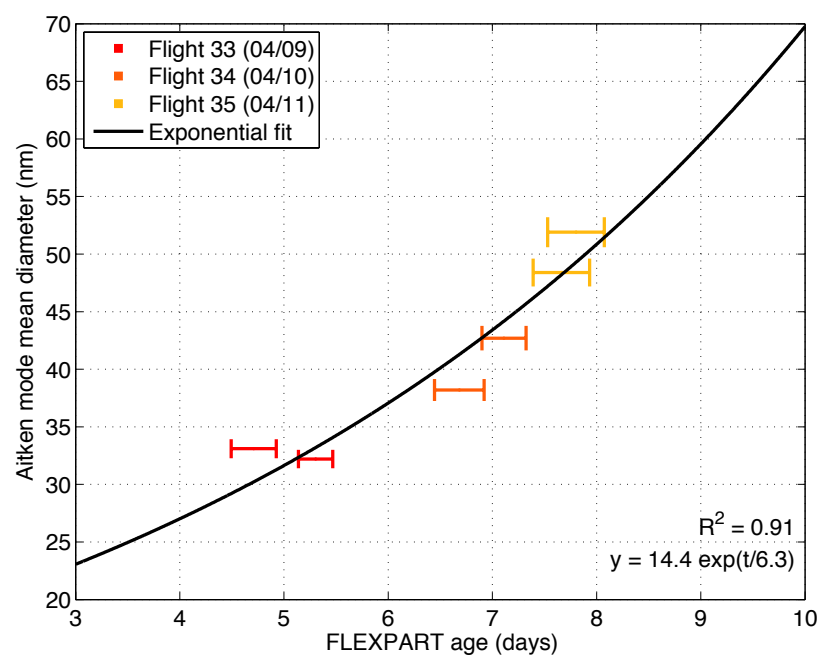

Fig. 5a. Evolution of the Aitken mode mean diameter as a function of the FLEXPART age for the anthropogenic plume. Data points are colour-coded with respect to the flight dates. An exponential fit shown as a black line.

\section{Case 1: anthropogenic plume sampled during three consecutive days}

During flights on 9, 10 and 11 of April 2008 (flight number 33, 34 and 35, respectively), an anthropogenic air mass was sampled during three consecutive days by the ATR-42 French aircraft (see Fig. 1). It originated from areas in central Europe as seen on the FPES maps shown in Fig. 2 and was sampled at an altitude between 4 and $5 \mathrm{~km}$. The anthropogenic origin of the plume is supported by the fact that no hot spot influence was detected by MODIS. In addition, Lagrangian calculations using the FLEXTRA model show the strong plume coherence between the sampling periods.

\subsection{Aerosol size distributions evolution}

Figure 3 presents the evolution of the aerosol number size distribution the flight performed on 9 April. The two mea-

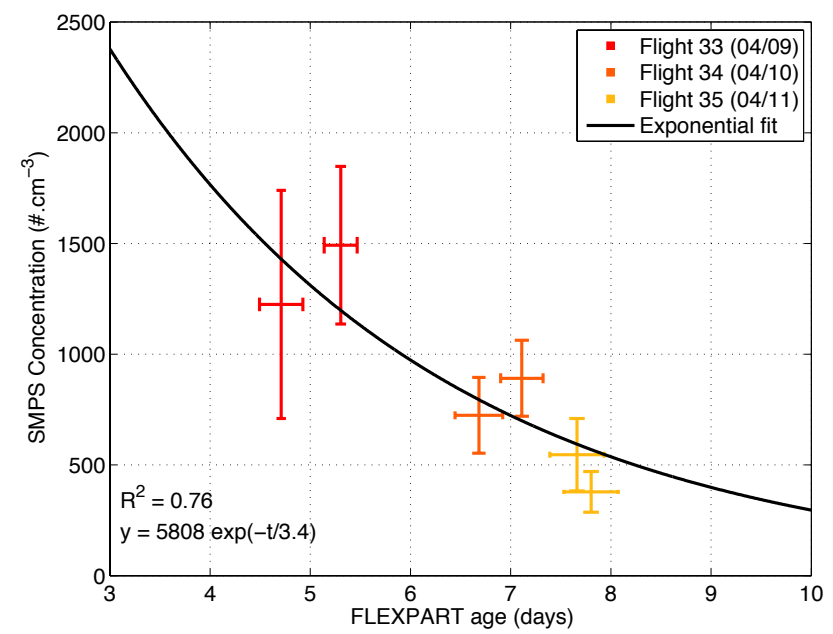

Fig. 5b. Evolution of the SMPS concentration $(20-450 \mathrm{~nm})$ as a function of the FLEXPART age for the anthropogenic plume. Data points are colour coded with respect to flight dates and an exponential fit is shown as a black line.

surement periods corresponding to the anthropogenic plume are indicated with red rectangles. A strong Aitken mode appears during the periods when the anthropogenic plume was encountered. For all three flights sampling this air mass, aerosol size distributions averaged over the sampling periods are plotted in Fig. 4. In addition, a typical polar background size distribution at this altitude $(4000 \mathrm{~m})$ is shown in blue. Parametrisations of size distributions calculated from log-normal fits with three size modes, are added in this figure. The log-normal parameters, i.e., the number concentrations $N_{i}$, the standard deviation $\sigma_{i}$ and the mean diameter $D_{\text {mi }}$ related to mode $i$ (ranging from 1 to 3 ) are reported in Table 2. The constraints used for the lognormal fit of each mode are given in Table 3 . The highly concentrated Aitken mode $\left(860 \mathrm{~cm}^{-3}\right)$, centred around $33 \mathrm{~nm}$ mean diameter for the first sampling flight evolves to larger mean diameters ( $51 \mathrm{~nm}$ for the third flight). Notice that the time since emission of the sampled pollution plume increased by 
Table 3. Constraints used in the log-normal parameterisations for aerosol modes.

\begin{tabular}{llrcc}
\hline Parameterisation & Aitken mode & Accumulation mode 1 & Accumulation mode 2 & Coarse mode \\
\hline European anth. & $20 \leq D_{\mathrm{p}}<90 \mathrm{~nm}$ & $90 \leq D_{\mathrm{p}}<500 \mathrm{~nm}$ & - & $500 \leq D_{\mathrm{p}}<2000 \mathrm{~nm}$ \\
European fires & $20 \leq D_{\mathrm{p}}<110 \mathrm{~nm}$ & $110 \leq D_{\mathrm{p}}<700 \mathrm{~nm}$ & - & $700 \leq D_{\mathrm{p}}<2000 \mathrm{~nm}$ \\
Asian mixed & $20 \leq D_{\mathrm{p}}<90 \mathrm{~nm}$ & $90 \leq D_{\mathrm{p}}<200 \mathrm{~nm}$ & $200 \leq D_{\mathrm{p}}<700 \mathrm{~nm}$ & $700 \leq D_{\mathrm{p}}<2000 \mathrm{~nm}$ \\
\hline
\end{tabular}
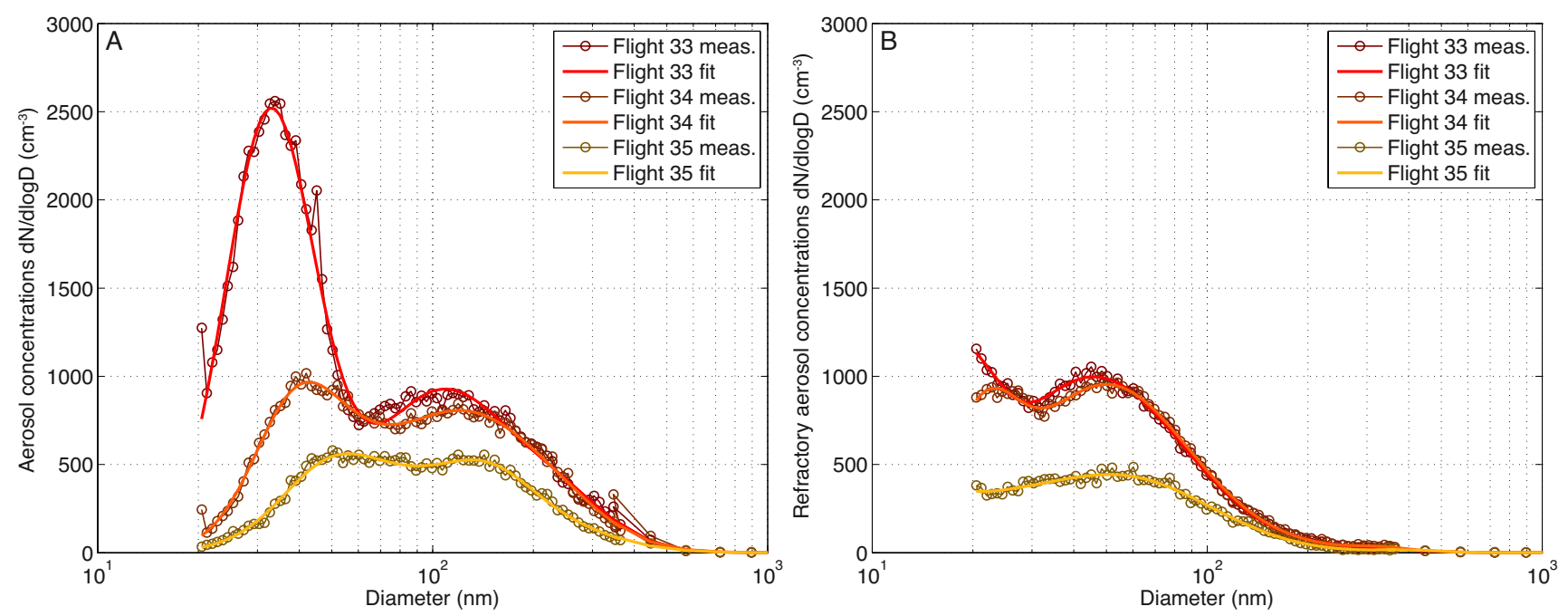

Fig. 6. (A) Ambient and (B) $280^{\circ} \mathrm{C}$ aerosol number size distributions for flights on 9,10 and 11 April.

about three days between the first and the third flight (Table 2, Fig. 2). The evolution of the aerosol size distribution observed during the three subsequent flights, was simulated using a coagulation model. The results are presented more in detail in Sect. 3.3. Furthermore, the evolution of the Aitken mode mean diameter as a function of mean air mass age derived from FLEXPART source contributions as a function of time is parameterised with an exponential fit and shown in Fig. 5a. In the course of the three consecutive flights (9 to 11 April), the mean modal diameter of the Aitken mode increases exponentially. Because of the different processes affecting particle growth rates in very different ways during different stages of atmospheric transportation, the presented exponential parameterisation, however, becomes more and more uncertain when extrapolating the modal mean diameter (backward) close to the emission region. Between the 9 and 11 April, the accumulation mode mean diameter is shifted from 104 to $133 \mathrm{~nm}$ and the mean maximum accumulation mode concentration decreased from 920 to $515 \mathrm{~cm}^{-3}$ in $\mathrm{dN} / \mathrm{d} \log \mathrm{D}$. The decrease of accumulation mode number concentration (Fig. 5b) with ageing is attributed to coagulation and also to cloud processing. To investigate the presence of cloud on the pathway of the air mass on 10 and 11 April, the ECMWF (European Center for Meteorological Weather Forcast) cloud cover and total precipitation product and HYSPLIT on-line version of the Lagrangian backtrajectory model (Draxler and Rolph, 2010; Rolph, 2010) were used. Figure 9 presents the vertical profiles of ECMWF cloud cover along the HYSPLIT calculated backtrajectory positions. Simulations were initialised for 10 and 11 April at 10:00 and 13:00 UTC in each case and show cloud processing after 9 April. Finally, the corresponding ECMWF total precipitation product suggests that, despite potential cloud processing precipitation scavenging did not occur.

\subsection{Refractory aerosol particles}

Ambient and elevated $\left(280^{\circ} \mathrm{C}\right)$ temperature systems can give evidence on the state of mixture of aerosol particles, for example, to what extent accumulation mode aerosol particles have been coated. The ambient and heated aerosol number size distributions are presented in Fig. $6 a$ and $b$ for flights on 9, 10 and 11 July. Between the first and third sampling day of the European anthropogenic air mass, ambient $(104$ to $133 \mathrm{~nm})$ and heated $(43.4$ to $58.9 \mathrm{~nm})$ accumulation mode modal diameter increased by $29 \%$, whereas the corresponding refractory mode modal diameter (resulting from desorbed ambient accumulation mode) increased by $33 \% . F_{\text {conc,ac }}$ is rather constant during the 6 selected periods with a mean value of 1.14 , indicating that the entire ambient accumulation mode can be found in the refractory mode (hence, shifted to smaller sizes between 43 and $59 \mathrm{~nm}$ ). This ratio is greater than one since refractory Aitken mode particles may partly appear in the mode of refractory 


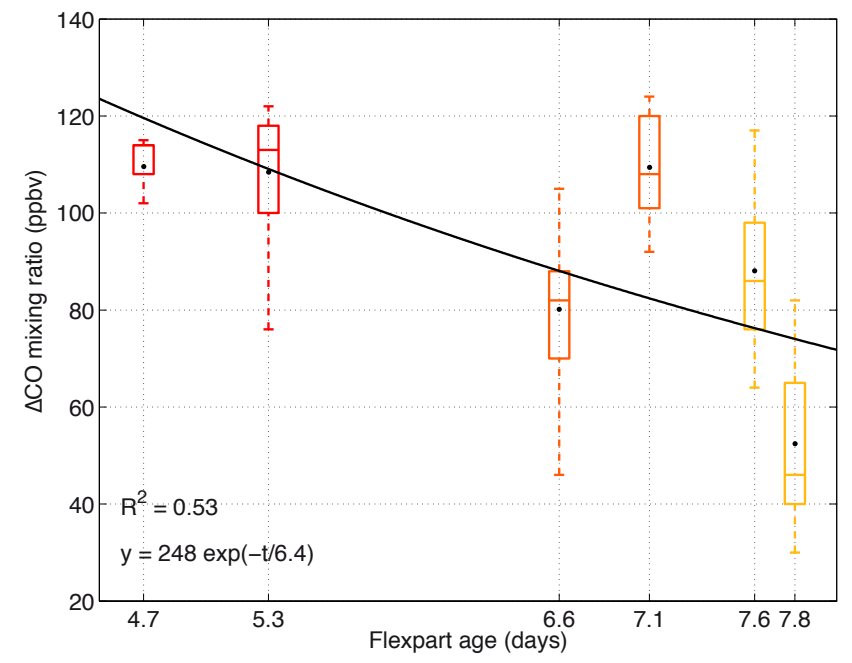

Fig. 7a. Evolution of the enhanced carbon monoxide mixing ratios (ppbv) as a function of FLEXPART age for the anthropogenic plume samplings. An exponential fit is shown. For each boxplot, the central line is the median, edges of the box are 25 th and 75 th percentiles and the dotted line extends to the 5th and 95th percentiles. The mean is indicated by black dots.

accumulation mode particles. This result highlights the internal mixing of the aerosol accumulation mode of this anthropogenic air mass. $F_{\text {volatile,ac }}$ is also rather constant during the first two flights and decreased during the last flight. Its mean value is 0.79 , thus, indicating that $79 \%$ of the accumulation mode volume was composed of volatile compounds. Unfortunately, the instrumentation mounted on the ATR-42 did not allow determining the chemical composition of the refractory and volatile aerosol fractions. In addition, the evolution of the Aitken mode after desorption dropped below $20 \mathrm{~nm}$ and could not be measured with the NVSMPS system.

\subsection{Air mass properties evolution}

The evolution of physico-chemical properties of the air masses measured on the ATR-42 and related to the anthropogenic air mass from central Europe is presented in Fig. 7a and $7 \mathrm{~b}$. These box plots present the median values as well as 25th and 75th percentiles (box edges) and also the 5th and 95th percentiles (dotted line edges). The mean values are indicated with black dots.

First, Fig. 7a presents the evolution of the enhanced gas phase $\mathrm{CO}(\triangle \mathrm{CO})$ mixing ratio in ppbv over the background value of $120 \mathrm{ppbv}$ as a function of the FLEXPART age. $\Delta \mathrm{CO}$ decreases exponentially (fitted black line) with a time scale of $\tau=6.4$ days. An estimation of the $\Delta \mathrm{CO}$ concentration near the source region is around $248 \mathrm{ppbv}$. The rather low correlation coefficient $\left(r^{2}=0.41\right)$ suggests that the pollution plume was heterogeneous and that the aircraft may have sampled somewhat different parts of the plume during the three

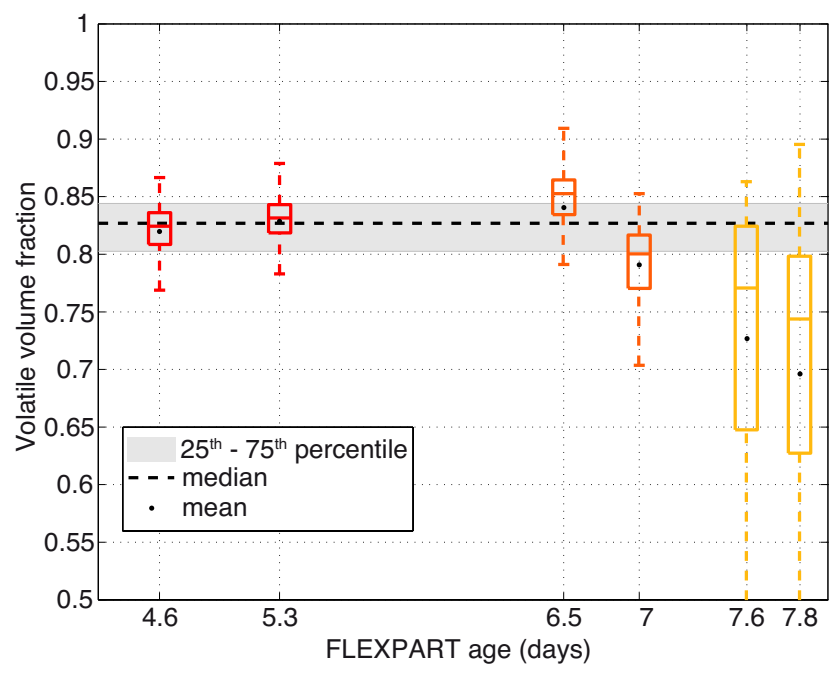

Fig. 7b. Presentation of aerosol $F_{\text {volatile }}$ as a function of the FLEXPART derived age of air masses. The mean volatile volume fraction for the 6 flight segments is plotted in black.

flight missions. The overall decrease of excess $\mathrm{CO}$ with time is likely due to dilution of the plume.

Finally, Fig. $7 \mathrm{~b}$ shows $F_{\text {volatile }}$ of the aerosol population as function of the FLEXPART age. This parameter is related to the condensed (rather volatile) material, i.e., coating of aerosol particles. $F_{\text {volatile }}$ is constant during the first four periods with a mean value of $0.81 \pm 0.09$, but decreases over the last two periods. This implies that the relative chemical composition of the particles within the air mass did not change considerably between the first and the second flight.

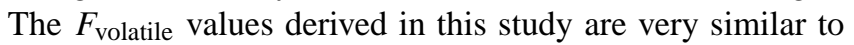
what has been published for long-term observations made by Häkkinen et al. (2012). Häkkinen et al. (2012) present results from long-term measurements of non-volatile aerosol fractions at the ground-based station of Hyytiälä, Finland. Their results support our findings, since Häkkinen et al. (2012) found that during spring season, the main source of aerosol was anthropogenic with a volatile aerosol fraction of 0.17. Both Häkkinen et al. (2012) and this study found higher aerosol volatile fractions than Birmili et al. (2010) who published a $F_{\text {volatile value of } 0.69 \text { for urban background }}$

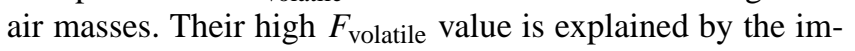
portant amount of volatile compounds released by anthropogenic pollution. Accordingly, we may conclude that such volatile compounds may have condensed on particles during transport to the Arctic.

\subsection{Modelling of the coagulation process}

The coagulation process appears to have been an efficient process governing the ageing of the European anthropogenic air mass. To confirm this statement, a modelling study of the coagulation process was performed with a time step of 
Table 4. Comparison between log-normally fitted observed and simulated aerosol number size distribution parameters.

\begin{tabular}{ll|rrr|rrrr}
\hline \multirow{2}{*}{ Flight date } & & \multicolumn{3}{|c|}{ Aitken mode } & \multicolumn{4}{|c}{ Accumulation mode } \\
& & $n_{1}\left(\mathrm{~cm}^{-3}\right)$ & $\sigma_{1}$ & $d_{\mathrm{m} 1}(\mathrm{~nm})$ & $n_{2}\left(\mathrm{~cm}^{-3}\right)$ & $\sigma_{2}$ & $d_{\mathrm{m} 2}(\mathrm{~nm})$ \\
\hline \multirow{2}{*}{10 April } & Obs. & 313 & 1.36 & 40.4 & 493 & 1.75 & 128.9 \\
& Sim. & 237 & 1.30 & 38.8 & 321 & 1.70 & 115.0 \\
\hline \multirow{2}{*}{11 April } & Obs. & 174 & 1.45 & 50.1 & 285 & 1.63 & 134,0 \\
& Sim. & 166 & 1.30 & 41.1 & 263 & 1.65 & 118.1 \\
\hline
\end{tabular}

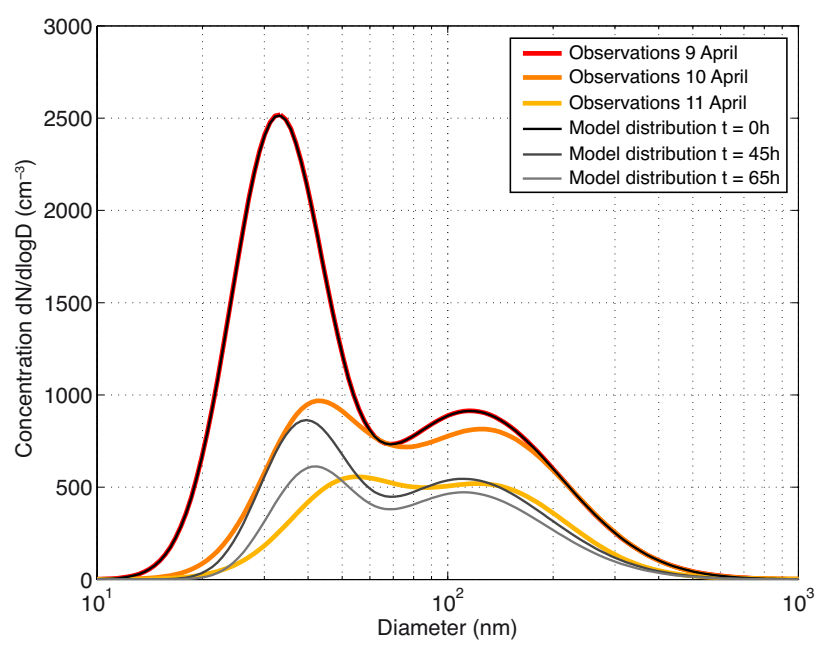

Fig. 8. Aerosol number size distributions observed (coloured lines) and simulated with a coagulation model (grey level lines) for flights on 9, 10 and 11 April. $t=0$ corresponds to the mean FLEXPART age for the measurements of the plume on 9 April. See text for details.

100 seconds, starting from the mean aerosol size distribution on 9 April and using a semi implicit coagulation model, based on particulate matter volume conservation, as presented in Jacobson (2005). Figure 8 shows the modelled distributions after coagulation superimposed on the measured distributions. The Aitken and accumulation mode parameters related to the observed and simulated distributions are presented in Table 4. Comparing the measurements on 9 to 11 April, the observed Aitken mode modal mean diameter shifted from 32.6 to $50.1 \mathrm{~nm}$, while the simulated modal mean diameter shifted from 32.6 to $41.1 \mathrm{~nm}$. Thus, the simulation can explain about half of the modal mean diameter evolution. Condensation processes are probably responsible for the other half of the growth. Since, coagulation is the only process which impacts particle concentrations, evolution of the simulated Aitken mode modal concentrations are in good agreement, $237 \mathrm{~cm}^{-3}$ (on the second day) and $167 \mathrm{~cm}^{-3}$ on the third day) are close to the measured concentrations of 313 and $174 \mathrm{~cm}^{-3}$ for 10 and 11 April, respectively.

However, the modelling of the accumulation mode particle evolution due to coagulation is less correlated with the obser- vations. Whereas the simulated modal mean diameter shifted from 116.8 to $118.1 \mathrm{~nm}$, the observed modal mean diameter shifted from 116.8 to $134 \mathrm{~nm}$. Thus, the coagulation explains only $10 \%$ of the modal mean diameter evolution. As demonstrated for the Aitken mode, the accumulation mode modal concentration is matches well the observed $\left(285 \mathrm{~cm}^{-3}\right)$ and simulated $\left(263 \mathrm{~cm}^{-3}\right)$ concentrations on 11 April.

Hence, both the Aitken as well as the accumulation mode modal diameter evolution cannot be explained solely by coagulation. Thus, the processes of condensation and ageing of particulate matter helps to explain the entire modal diameter evolutions. To support the hypothesis, Merlaud et al. (2011) found enhanced gaseous $\mathrm{NO}_{2}$ concentration measurements in the plume sampled on 9 April. $\mathrm{NO}_{2}$, through oxidation reactions in the atmosphere, can form $\mathrm{N}_{2} \mathrm{O}_{5}$ and $\mathrm{NO}_{3}$ compounds which are able to interact with aerosol particles (Mentel et al., 1996; Hallquist et al., 2000; Benton et al., 2010). However, it is difficult to evaluate the impact of condensation processes since they cannot be simulated without a complete suite of measurements of potential condensable gases. In addition, condensation is, of course, occurring from 9 (and probably before) to 11 April and should impact the modal mean diameter evolutions during all three days of the study. The following relationship links particle diameter to the shift of the diameter due to condensation processes:

$\frac{\mathrm{d} D_{\mathrm{p}}}{\mathrm{d} t}=\frac{4 D_{i} M_{i}}{R T D_{\mathrm{p}} \rho_{\mathrm{p}}} f(K n, \alpha)\left(p_{i}-p_{\mathrm{eq}}\right)$

with $D_{i}$ and $M_{i}$ are diffusion coefficient and molecular weight of the gas $i, R$ is the ideal gas constant, $T$ the medium temperature, $\rho_{\mathrm{p}}$ the particle density, $f(K n, \alpha)$ is a correction factor related to discontinuity effects and finally, $p_{i}$ is the partial pressure of the corresponding species while $p_{\text {eq }}$ is the total gas pressure at the equilibrium. According to Eq. (4), the Aitken mode particle diameter growth rate should have been more impacted by condensation processes than the accumulation mode particle diameter growth rate. However, cloud processing (as seen in Fig. 9) occurring upstream the sampling after 9 April most likely impacted the accumulation mode. 

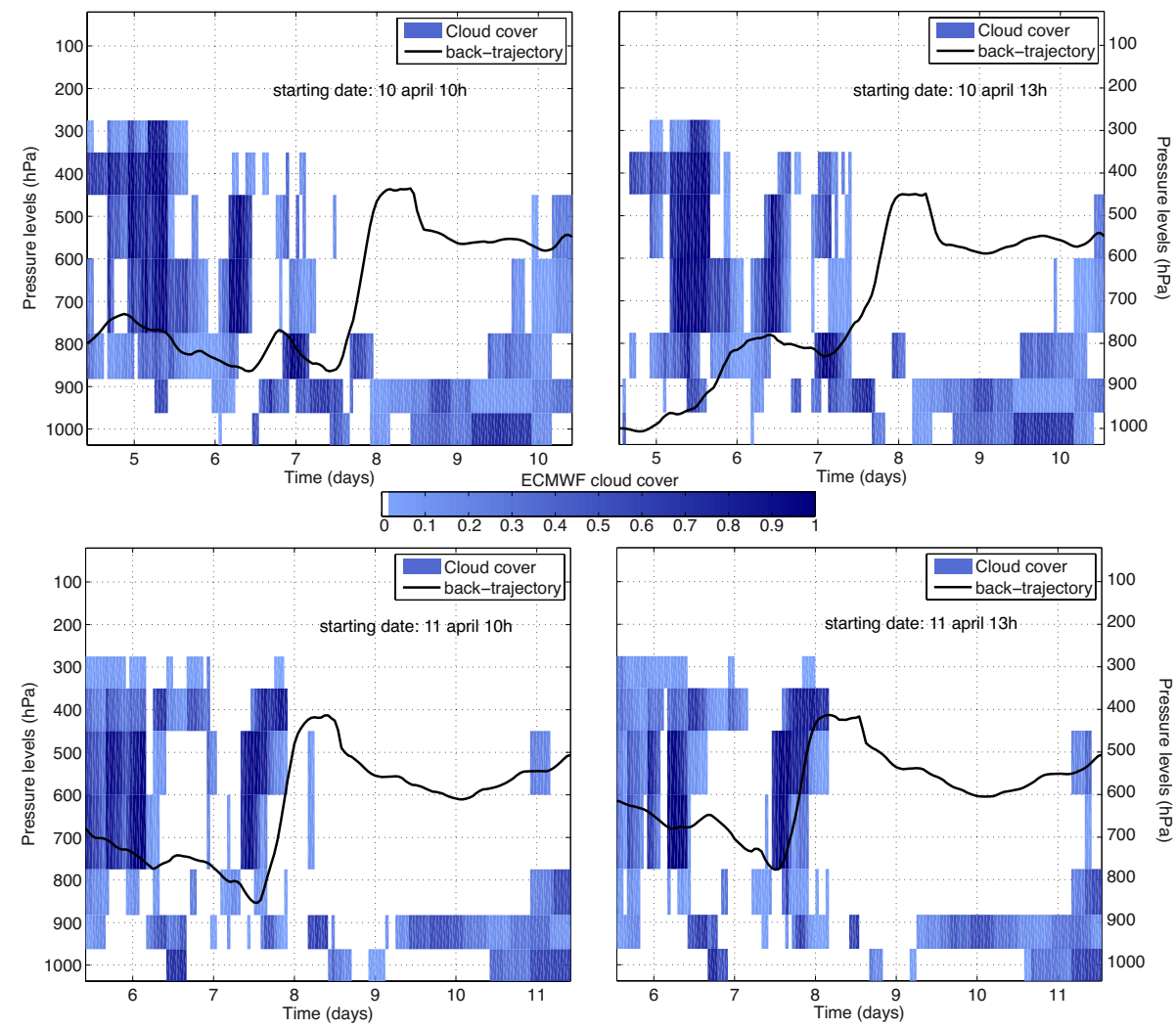

Fig. 9. ECMWF cloud cover along the HYSPLIT back-trajectories corresponding to the European anthropogenic air mass.

\section{Case 2: Eurasian polluted plumes}

During flights on 8 (AM and PM), 9, 10 and 11 April, several pollution plumes were sampled by the ATR-42, such as from biomass fires in eastern Europe (north of the Black Sea) and forest fires in Siberia (see Fig. 10). Moreover, air masses with eastern Asia anthropogenic pollution particles were sampled. The Asian plume anthropogenic and biomass burning origins, discussed in Adam de Villiers et al. (2010) are investigated in the subsequent section. Compared to the European anthropogenic plume discussed in the previous section, plumes presented in the following section are referred to as Eurasian pollution plumes.

\subsection{Aerosol size distributions}

During the POLARCAT-France spring campaign, 6 periods related to Eurasian pollution transported to the Arctic were identified using FLEXPART PES: Four plumes corresponding to Russian fires, located at the north of the Black Sea, subsequently denoted Russian fires (RF) and transported over Europe to the sampling location and two plumes corresponding to air masses containing a mixture of Siberian fires and eastern Asia anthropogenic emissions, called hereafter Asian fires (AF) and Asian anthropogenic (AA), respectively. Asian plumes denoted (AF) and (AR) were both trans-

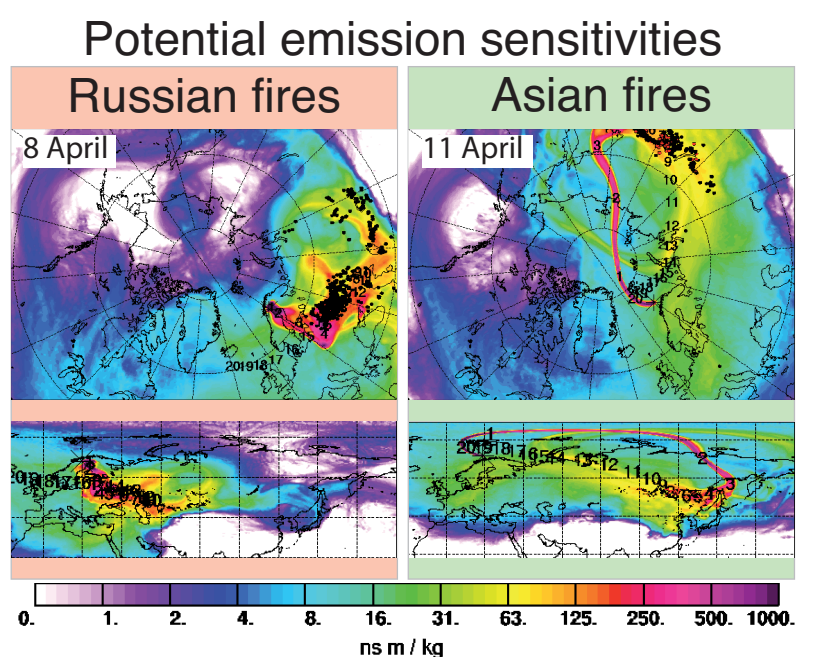

Fig. 10. FLEXPART column-integrated potential emission sensitivities for Russian (left) and Asian (right) forest fire plumes. Black and red dots represent agricultural and forest fires, respectively.

ported over the North Pole to the sampling location and were clearly visible in aerosol Lidar measurements, as presented in Adam de Villiers et al. (2010). Examples of PES corresponding to Russian and Siberian fire origins are presented 


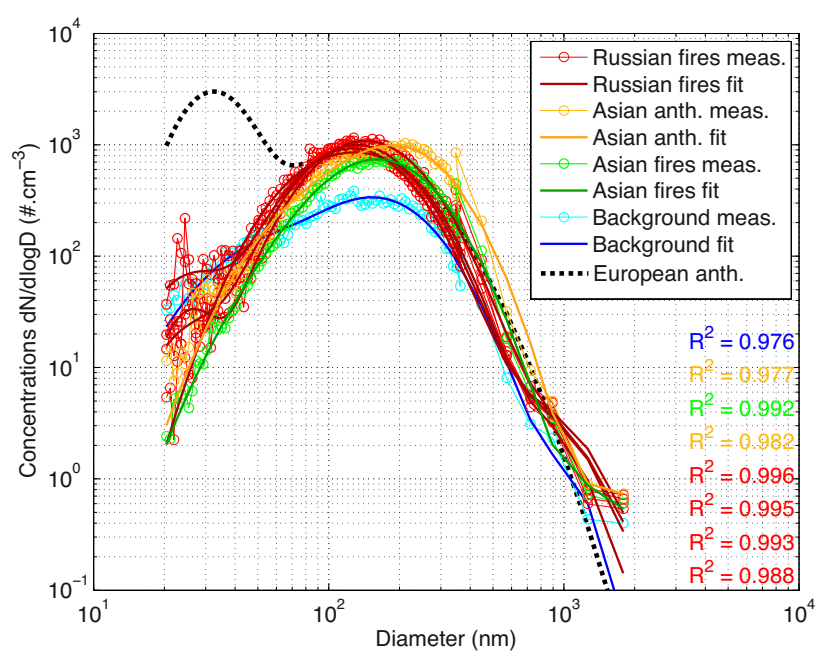

Fig. 11. Measured (thin solid line with circles) and fitted (thick solid line) aerosol number size distributions corresponding to Russian and Asian plumes transported to the Arctic. Distributions are fitted with three mode, corresponding correlation factors are indicated. Red and green distributions represent Russian and Asian forest fires, respectively; yellow distributions represent the Asian anthropogenic plume. For comparison reason, a polar background distribution is shown in blue and in addition, a distribution related to the European anthropogenic plume sampled on 9 April (discussed in the first case study).

in Fig. 10. Mean aerosol size distributions and log-normally fitted distributions for the pollution plumes originated from Russian fires, Asian fires and Asian anthropogenic emissions are shown in Fig. 11. Size distributions related to Russian and Asian fire plumes are plotted in red and green, respectively, while that related to the anthropogenic air masses is plotted in yellow. In order to illustrate the enhancement in particle concentrations over usual Arctic background concentrations, a background aerosol size distribution (selection supported from PES and FPES analysis, indicating local origins) is added in blue on Fig. 11. Parameters related to the log-normal parameterisations (three or four modes) of the aerosol size distributions are presented in Table 5.

Concerning the observed Eurasian pollution plume, aerosol size distributions are characterised by the highly concentrated accumulation mode and very low Aitken mode particle concentrations as seen in Fig. 11. The FLEXPART ages are reported in Table 5. While the Aitken mode was the main contributor to the total particle concentration of the European anthropogenic plume (Sect. 3), Russian fires and Asian polluted plumes were mostly characterised by large accumulation mode particles. According to these findings, Eurasian pollution plume air masses, especially from anthropogenic origins were expected to be older than the anthropogenic European ones. The air mass ages calculated from FLEXPART for the Eurasian plumes are similar to ages of the European anthropogenic plumes discussed in the previous section (5.37.4 days).

With respect to the log-normal parameterisations (see Table 5), for Asian air masses, two modes have been necessary in the diameter range usually associated to the accumulation mode $(100-300 \mathrm{~nm})$. The first mode with a modal mean diameter of $150 \mathrm{~nm}$ is related to forest fires while the second mode, centred on $250 \mathrm{~nm}$, might be linked to anthropogenic emissions. These assumptions are based on Adam de Villiers et al. (2010) who discussed these two air masses (AF) and (AA) in their study. Both air masses were composed of a mixing between biomass burning and anthropogenic contributions. In their study, Adam de Villiers et al. (2010) found evidence on the different intensity of the anthropogenic contribution in these two air masses. This intensity of the anthropogenic contribution can be seen in the fitted concentrations of the second accumulation mode (149 and $35 \mathrm{~cm}^{-3}$ ), as shown in Fig. 12b and c. When comparing these air masses to the European air masses, air mass ages (roughly five days) are rather similar. However, aerosol size distributions are completely different for European (first case study) and Asian (second case study) air mass origins. Whereas the European Aitken and accumulation mode maxima are of the order of 2400 and $920 \mathrm{~cm}^{-3}$ in $\mathrm{dN} / \mathrm{dlog} \mathrm{D}$ plots, with corresponding mode diameters of 33.1 and $116.8 \mathrm{~nm}$, respectively, the maxima are on the order of 240 and $860 \mathrm{~cm}^{-3}$ in $\mathrm{dN} / \mathrm{d} \log \mathrm{D}$, with mode diameters of 74.5 and $200.1 \mathrm{~nm}$ for the Asian plumes (Asian accumulation mode concentrations correspond to the sum of both modelled modes).

The mean size of particle modes observed can be related to the mean size of particles at the emission site (depending on the source type) and the processing of particle during transportation (depending on the initial particle size distribution, the amount of aerosol precursors and the time available). In this case study, the information about the aerosol properties in the source region is insufficient. Thus, the differences in the Aitken mode concentration may be explained by (i) Asian particles emitted with larger diameters and a small amount of Aitken mode particles (which may, in addition, involve a large condensational sink and exclude secondary nucleation) or (ii) nucleation events occurring in European air masses during transport. Both hypotheses are difficult to prove, primarily due to the lack of information on particle emissions at the source. However, the following section presents the analysis of ambient and refractory aerosol size distributions and, thus, the aerosol volatile volume fraction in order to shed light on the source contributions to the size distributions.

\subsection{Refractory aerosol particles}

The volatility behaviour (particle number and volume) of aerosol particles from Russian and Asian fires as well as from Asian anthropogenic sources is derived from ambient and heated number size distributions. Concentrations and mean modal diameters for ambient and heated distributions are 
Table 5. Parameterisation of log-normally fitted size distributions for forest fire plumes. FLEXPART determined air mass ages are also indicated.

\begin{tabular}{|c|c|c|c|c|c|c|c|c|c|c|c|c|c|}
\hline \multirow{2}{*}{ Air mass type } & \multirow{2}{*}{$\begin{array}{c}\text { Flexpart age } \\
\text { (days) }\end{array}$} & \multicolumn{3}{|c|}{ Aitken mode } & \multicolumn{3}{|c|}{ Accumulation mode 1} & \multicolumn{3}{|c|}{ Accumulation mode 2} & \multicolumn{3}{|c|}{ Coarse mode } \\
\hline & & $n_{1}\left(\mathrm{~cm}^{-3}\right)$ & $\sigma_{1}$ & $d_{\mathrm{m} 1}(\mathrm{~nm})$ & $n_{2}\left(\mathrm{~cm}^{-3}\right)$ & $\sigma_{2}$ & $d_{\mathrm{m} 2}(\mathrm{~nm})$ & $n_{3}\left(\mathrm{~cm}^{-3}\right)$ & $\sigma_{3}$ & $d_{\mathrm{m} 3}(\mathrm{~nm})$ & $n_{4}\left(\mathrm{~cm}^{-3}\right)$ & $\sigma_{4}$ & $d_{\mathrm{m} 4}(\mathrm{~nm})$ \\
\hline \multirow{4}{*}{ Russian fires } & 5.3 & 25.6 & 1.43 & 26.5 & 488 & 1.62 & 125.5 & - & - & - & 2.2 & 1.57 & 700 \\
\hline & 5.5 & 8.4 & 1.4 & 27.7 & 515 & 1.61 & 131.2 & - & - & - & 1.81 & 1.53 & 700 \\
\hline & 6.8 & 7.9 & 1.26 & 26.0 & 565 & 1.61 & 143.5 & - & - & - & 1.75 & 1.57 & 700 \\
\hline & 7.4 & 332 & 1.60 & 101.6 & 183 & 1.50 & 183.2 & - & - & - & 1.39 & 1.45 & 700 \\
\hline Asian anth. & 5 & 7.8 & 1.20 & 32.5 & 433 & 1.67 & 145.4 & 149 & 1.37 & 253.3 & 0.88 & 1.30 & 852 \\
\hline Asian fires & 6.6 & 3.9 & 1.45 & 39.9 & 380 & 1.67 & 150.2 & 36 & 1.30 & 249.9 & 0.34 & 1.52 & 1271 \\
\hline Background & & 84.8 & 1.80 & 61.2 & 157 & 1.62 & 165.6 & - & - & - & 0.303 & 1.30 & 941 \\
\hline
\end{tabular}

Table 6. Parameterisation of log-normally fitted refractory size distributions for forest fire plumes.

\begin{tabular}{l|ccc|ccc|ccc}
\hline \multirow{2}{*}{ Air mass type } & \multicolumn{3}{|c|}{ refractory mode 1 } & \multicolumn{3}{|c}{ refractory mode 2 } & \multicolumn{4}{c}{ refractory mode 3 } \\
& $n_{1}\left(\mathrm{~cm}^{-3}\right)$ & $\sigma_{1}$ & $d_{\mathrm{m} 1}(\mathrm{~nm})$ & $n_{2}\left(\mathrm{~cm}^{-3}\right)$ & $\sigma_{2}$ & $d_{\mathrm{m} 2}(\mathrm{~nm})$ & $n_{3}\left(\mathrm{~cm}^{-3}\right)$ & $\sigma_{3}$ & $d_{\mathrm{m} 3}(\mathrm{~nm})$ \\
\hline \multirow{3}{*}{ Russian fires } & 85 & 1.80 & 27.9 & 406 & 1.57 & 74.2 & 11 & 1.68 & 298.3 \\
& 27 & 1.31 & 24.5 & 494 & 1.54 & 71.9 & 35 & 1.90 & 168.7 \\
& 53 & 1.59 & 25.4 & 513 & 1.53 & 77.6 & 79 & 1.89 & 130.0 \\
& 174 & 1.80 & 24.8 & 372 & 1.57 & 73.5 & 23 & 1.88 & 191.1 \\
\hline Asian anth. & 86 & 1.76 & 26.6 & 353 & 1.49 & 75.3 & 160 & 1.48 & 150.1 \\
\hline Asian fires & 58 & 1.48 & 27.1 & 393 & 1.63 & 77.8 & 18 & 1.90 & 203.1 \\
\hline
\end{tabular}

given in Tables 5 and 6 , respectively. Figure 12a presents the mean ambient and desorbed size distribution for Russian fires. As described in the previous section, ambient particle size distributions are dominated by the highly concentrated accumulation mode. The mean refractory (or desorbed) size distribution shows a similar shape with a highly desorbed former accumulation mode preserving particle concentrations, as seen in the calculated $F_{\text {conc,ac }}$ mean value of 0.96 for the related periods. The mean value of 0.79 for the derived accumulation mode volatile volume fraction $F_{\text {volatile, ac highlights }}$ the high volatility of the accumulation mode of the Russian fire plume particles. This is also illustrated by the important shift in the modal mean diameter from 127.0 to $74.2 \mathrm{~nm}$. A second, but rather refractory mode is found with a very low concentration at a modal diameter of $27 \mathrm{~nm}$.

The Asian air masses (fires and mixed emissions) were also characterised by highly concentrated particles in the accumulation mode (Fig. 12b and c). As mentioned in Sect. 4, the accumulation mode is composed of two contributions described by two separate modes (anthropogenic and forest fires, Adam de Villiers et al., 2010) corresponding to mean diameters of roughly 150 and $240 \mathrm{~nm}$, respectively. For the Asian fires, the accumulation mode (at ambient temperature) desorbed to an almost mono-modal size distribution (at $280^{\circ} \mathrm{C}$ ) with a mean diameter of $78 \mathrm{~nm}$. This means that the properties of aerosol particle size distributions from Asian fires and Russian fires are very similar.

However, for the Asian anthropogenically influenced air masses, aerosol size distributions can be separated in two modes. A first mode which behaves very similarly to the dominant mode of the Asian fire air masses and a second mode which desorbed to a distinct refractory mode with a higher modal mean diameter, as compared to the dominant mode of the Asian fires. Regarding the modal diameters and concentrations of the two modes and what we learned from size distributions related to fires, the first mode then is associated to Asian fire emissions, while the second mode is attributed to a contribution from Asian anthropogenic emissions. A similar behaviour of an anthropogenic air mass was already presented by Pratt and Prather (2009) who observed aged urban particles, mostly composed of organic material, at ambient temperature and $230^{\circ} \mathrm{C}$ and found modal mean diameters of 242 and $177 \mathrm{~nm}$, respectively.

\section{$5 \quad$ In situ samples}

During the five last flights of the campaign, seven aerosol in situ samples were collected in clear sky conditions. Table 7 summarises information about the samples including the origin of the sampled air masses, flight dates, start and end time of sampling, and the corresponding relative humidity (RH). Figure 13 presents typical images of submicron aerosol particles sampled in different air masses. Clean polar air mass images clearly show satellite-like particles with a large drop surrounded by smaller droplets, as seen in Fig. 13a, which are typically a signature of acidic sulphate. The supposed acidity and absence of soot both indicates that the particles were not 

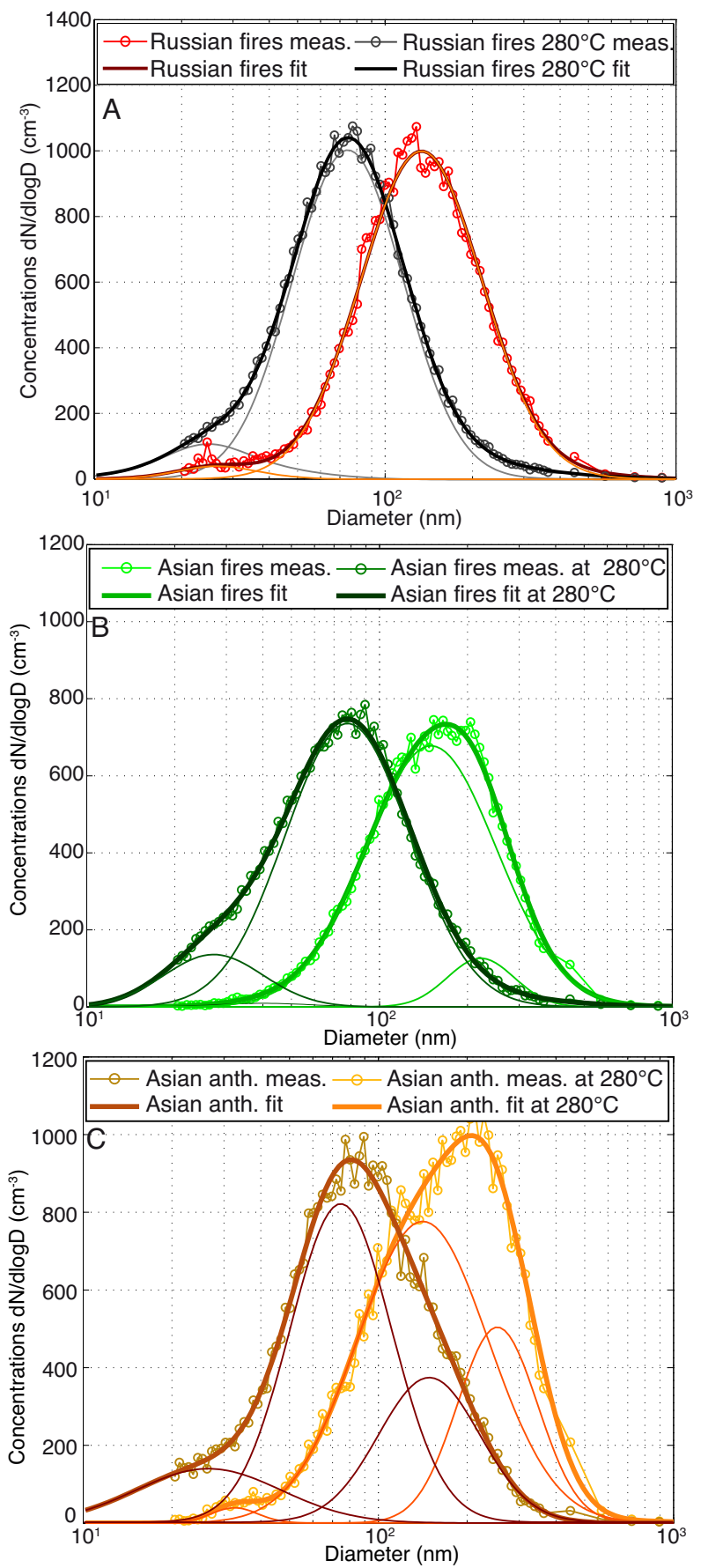

Fig. 12. Ambient and $280^{\circ} \mathrm{C}$ aerosol number size distributions for (a) Russian fires air masses and (b) Asian fire and (c) Asian anthropogenic air masses.

in close contact with the continental air masses. No obvious differences can be found between Russian fire and European anthropogenic particles, as shown in Fig. 13b and c where many particles left liquid like stain and soot like inclusions. RH may have had influence on the formation of the coating layer because those in Fig. 13d seem to have more solid,

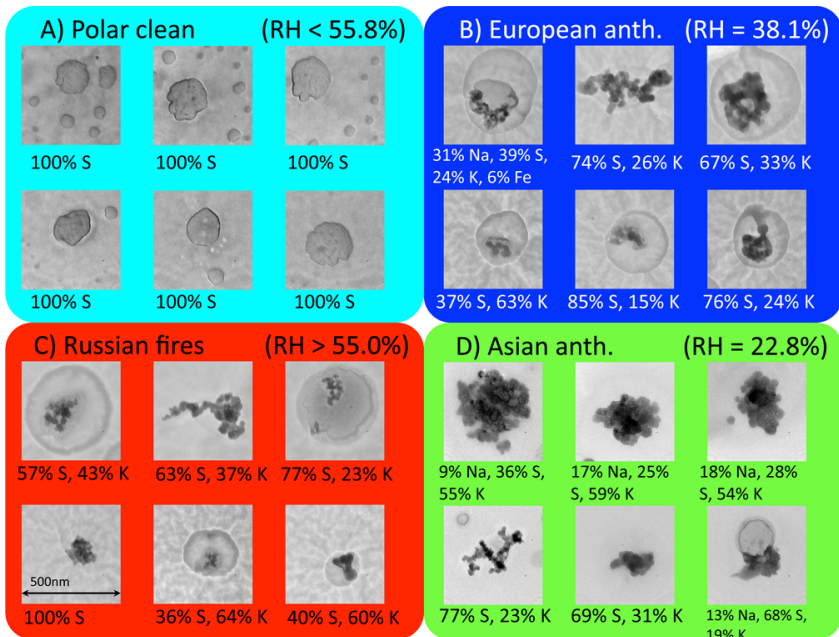

Fig. 13. Representative images of submicron aerosol particles sampled in situ during POLARCAT flights. Particle origins are: polar clean air (A), European anthropogenic (B), Russian fires (C) and Asian anthropogenic (D). Width of images corresponds to $500 \mathrm{~nm}$. Elemental compositions of particles, determined by EDX, are indicated in term of atomic ratio (C, N, O are excluded). See text for details.

crystalline like structure. Figure 13d images are for RH of $23 \%$ while Fig. $13 \mathrm{~b}$ and c images are for $\mathrm{RH}>40 \%$. Otherwise, the elements comprising the forest fire and anthropogenic particles were rather common.

The detection frequencies (DF) and atomic ratio (AR) of several elements found in analysed submicron aerosol samples are presented in Fig. 14a. Sulphur (S) is a major compound of sulphuric acid and sulphate and it is not surprising to find it with a $100 \%$ DF. However, sulphur is more concentrated in anthropogenic particles with an AR about $80 \%$. Potassium $(\mathrm{K})$ is considered as a biomass burning tracer (Andreae, 1983), but can be measured, to a lower extent, in fossil fuel emissions, too (Guazzotti et al., 2003). As shown in Fig. 14a, almost all particles from fire origins contain $\mathrm{K}$ while the DF of $\mathrm{K}$ decreases to $60 \%$ for anthropogenic particles and $20 \%$ for clean polar air. This trend in DF is similar in the AR (Fig. 14b). DF of soot-like inclusions depends on air mass origins, but cannot be clearly related to fire or anthropogenic origins. Analyses of supermicron samples mainly pointed out the predominence of alumino-silicate mineral dust particles, and to a lesser extent by sea salt. Unlike submicron particles, no clear-cut correlation regarding the air mass origins were found. Thus, the dust influence found by Adam de Villiers et al. (2010) in the Asian air masses can not be confirmed by the supermicron samples analysis.

\section{Summary and discussion}

This study focuses on the characterisation of pollution plumes transported to the Scandinavian Arctic during spring 
Table 7. TEM-EDX (submicron) and SEM-EDX (supermicron) samples of individual particles analysed for this study.

\begin{tabular}{lc|ccc|c}
\hline Air mass type & date & $\begin{array}{c}\text { start time } \\
\text { (HH:MM UTC) }\end{array}$ & $\begin{array}{c}\text { end time } \\
\text { (HH:MM UTC) }\end{array}$ & $\begin{array}{c}\text { submicronic } \\
\text { analysis }\end{array}$ & $\begin{array}{c}\mathrm{RH} \\
(\%)\end{array}$ \\
\hline European anth. & 9 April & $09: 39$ & $09: 47$ & analysed & 38.1 \\
\hline \multirow{3}{*}{ Russian fires } & 8 April & $08: 48$ & $09: 04$ & analysed & 99.0 \\
& 8 April & $13: 52$ & $13: 59$ & analysed & 82.6 \\
& 9 April & $12: 04$ & $12: 17$ & analysed & 55.0 \\
\hline Asian anth. & 11 April & $10: 42$ & $10: 52$ & analysed & 22.7 \\
\hline \multirow{2}{*}{ Polar clear air } & 8 April & $9: 33$ & $09: 37$ & analysed & 26.3 \\
& 11 April & $12: 16$ & $12: 27$ & analysed & 55.8 \\
\hline
\end{tabular}

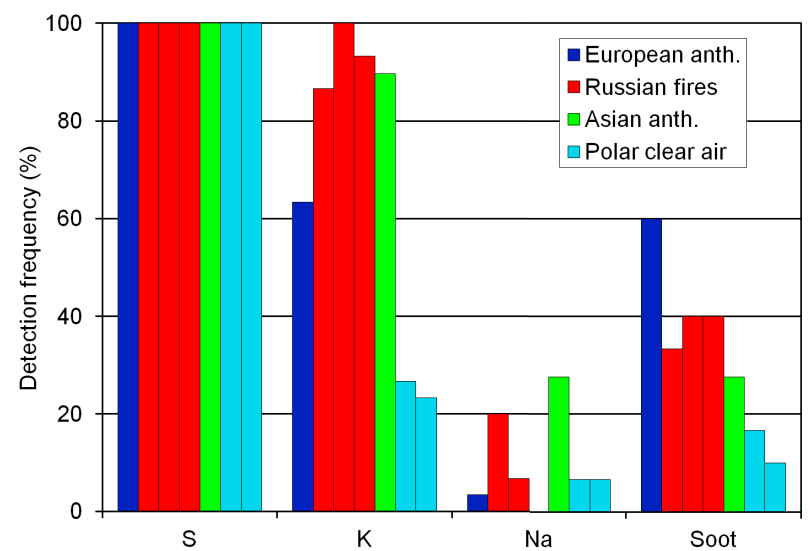

Fig. 14a. Detection frequency of the major elements (EDX) and soot (visual identification) among individual submicron aerosol particles.

of the year 2008. Two studies of transported air masses are presented here. Therein, the first case study investigates an European anthropogenic plume sampled during three consecutive flights, as seen by a Lagrangian study. Aerosol size distributions related to this plume illustrate particularly well the ageing of observed Aitken mode where concentration is decreasing (from 860 to $165 \mathrm{~cm}^{-3}$ in $\mathrm{dN} / \mathrm{d} \log \mathrm{D}$ ) and mean Aitken mode diameter is increasing (from 33 to $51 \mathrm{~nm}$ ) with plume age increasing from $5.0 \pm 0.2$ to $7.7 \pm 0.1$ days. Half of the Aitken mode evolution could be reproduced using a semi-implicit coagulation model, suggesting that other processes (cloud processing and condensation) are equally involved in the evolution of the Aitken mode (and also accumulation mode) particle diameters. In addition, the simulated Aitken mode modal concentrations were similar to the observations. Whereas the simulated accumulation mode concentration was in certainly limited agreement with the observations (recall that the pollution plume was heterogeneous and the aircraft may have sampled somewhat different parts of the more or less diluted/mixed plume during the three flight missions), the accumulation mode modal mean diameter evolution was less well reproduced by the coagulation model:

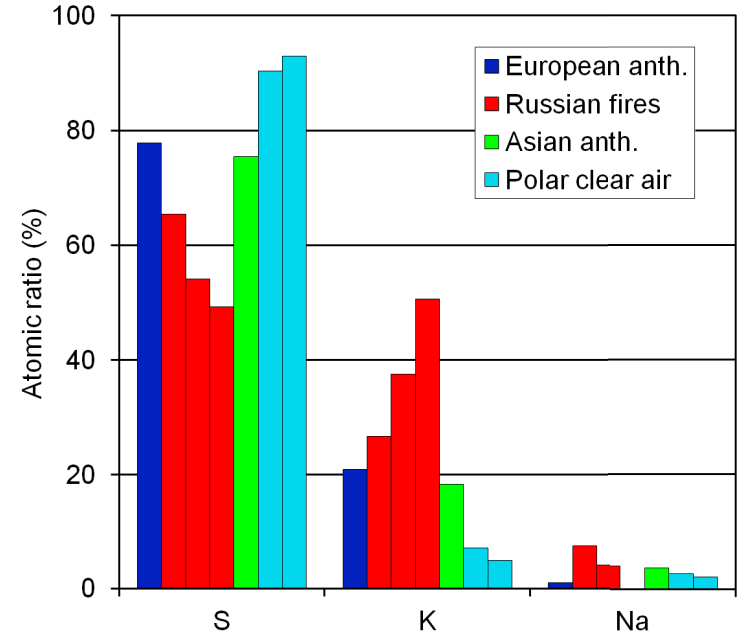

Fig. 14b. Atomic ratio of the major elements (EDX) among individual submicron aerosol particles.

only $10 \%$ of the modal diameter evolution can be related to the coagulation process. As a consequence, cloud processing of aerosol particles is suggested as the main process for accumulation mode modal mean diameter growth.

Related parameters like mean diameter of the Aitken mode, and $\triangle \mathrm{CO}$ mixing ratio exponentially decreased with ageing of the plume. Again, we have to state that variations with respect to the exponential fit are due to the plume heterogeneity. According to these exponential parameterisations, extrapolations of trends suggest that Aitken mode particles were emitted with an estimated $\triangle \mathrm{CO}$ mixing ratio of 248 ppbv. These values are in agreement with measurements performed over urban areas (McMeeking et al., 2010). This finding is also supported by the refractory distributions demonstrating that the Aitken mode particles were desorbed to sizes below the instrument lower detection limit of $20 \mathrm{~nm}$. The modal mean diameter of the refractory mode desorbed from the accumulation mode is increasing with time. This evolution is probably due to the ageing of organic materials. This growth in refractory core may compensate the gas 
phase condensation on particles and explain why the volatile volume fraction is constant.

The second case study focuses on air masses originating from Russia (north of Black Sea) and Asia (transported across the North Pole). Russian air masses were mostly influenced by large forest fires and present almost mono-modal aerosol number size distributions, on average, centred around $127 \mathrm{~nm}$ in the accumulation mode size range. This mode desorbed into a mode centred at $74 \mathrm{~nm}$ which means that aerosols in the russian fire plumes were internally mixed. Aerosols in Asian air masses had a more complex behaviour since their accumulation modes were found externally mixed and composed of two contributions (Adam de Villiers et al., 2010) from biomass burning and anthropogenic emissions with modal mean diameter at 150 and $240 \mathrm{~nm}$, respectively. These two contributions desorbed in two separate modes centred at 75 and $150 \mathrm{~nm}$, thus, corresponding to biomass burning and anthropogenic contributions, respectively. The modal concentrations were consistent in both ambient and refractory modes.

In order to compare the observation of this study with earlier studies, Fig. 15 presents modal mean diameters of aerosol size distributions as compared to their geometric standard deviation. Observations from earlier studies (Reid and Hobbs, 1998; Reid et al., 1998, 2005; Petzold et al., 2007) are indicated with black symbols while POLARCAT-spring observations are indicated with coloured dots. Whereas fire plumes are following similar linear regression trends as already observed in previous studies by Dentener et al. (2006) and Janhäll et al. (2010), the linear regression related to the anthropogenic plume is different. However, the deviation to the linear regression for anthropogenic plumes might be caused by only one data point. Therefore, the proposed regression should be considered with caution.

Finally, in situ submicron and supermicron aerosol particles samples were collected during the flights. Clear differences were found for plumes with different origins especially with respect to the potassium detection frequency and atomic ratio, which is highest in fire samples, then decreases for anthropogenic samples, and is lowest for clean air polar air masses. Sulfate was found in each particle sample. The observation of soot-like inclusions support that soot can be transported over larger time periods than expected ( $>5$ days), as claimed by Bourgeois and Bey (2011). In addition, particle images confirm differences between clean and polluted air mass origins of aerosol particles. Individual particles analysis show an internal mixing. Thus, the Asian air masses can be considered as an external mixing of two internally mixed contributions.

\section{Conclusions}

This study focuses on the characterisation of aerosol particles in pollution plumes transported to the Arctic. Two case

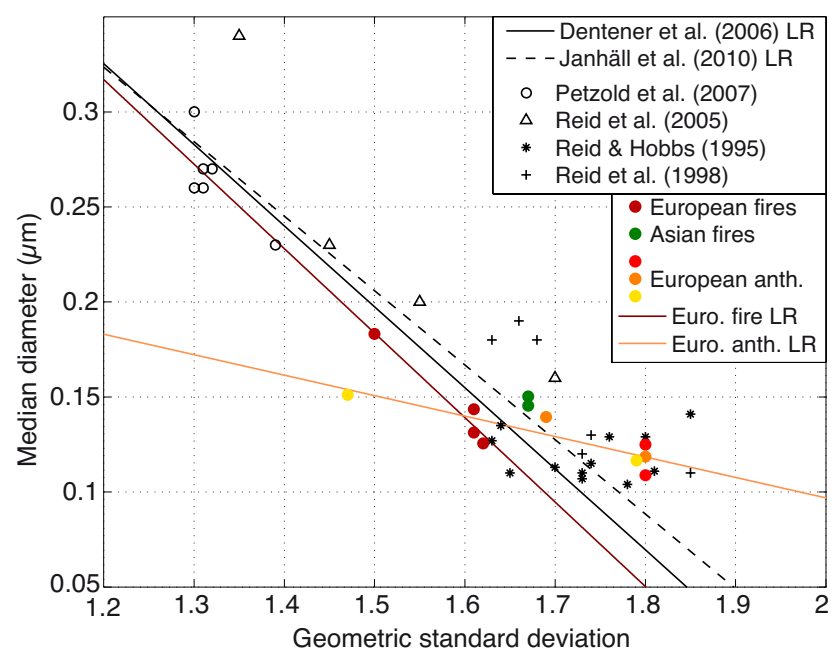

Fig. 15. Modal mean diameters for the accumulation mode of forest fire aerosol size distributions as a function of their geometric standard deviations. Values for the European anthropogenic plumes are indicated for comparison. Linear regression (LR) from earlier studies and for fires and anthropogenic plumes are also shown.

studies are presented. The first case study focuses on a European anthropogenic air mass sampled during three consecutive days. Between the samplings performed on the first day (9 April) and the subsequent two days (10 and 11 April) aerosol size distributions experienced cloud processing. The study conclude that cloud processing accounts for the most important contribution to modify the accumulation mode modal diameter, whereas the coagulation process only accounts for less than $10 \%$ of the modal mean diameter growth. In contrast, the Aitken mode modal mean diameter evolution can be explained to $50 \%$ with a pure coagulation model. Since the volatile volume fraction is rather similar along the three days, condensation of volatile compounds on particles equally contributed to particle growth. However, it is difficult to conclude more quantitatively on the impact of different processes on the aerosol size distribution evolution since more information is needed, especially about the properties and concentrations of particulate matter and condensable vapours at the source region. The data presented here can be used for an extended modelling study of the transport of air masses from the source region to the sampling area.

The second case study focuses on European and Asian biomass burning air masses. All observed forest fire air masses show similar characteristics with respect to the aerosol particle size distributions. In particular, the monomodal ambient aerosol distributions which desorbed to mono-modal refractory size distributions with modal mean diameters of 135 and $75 \mathrm{~nm}$, respectively. Finally, biomass burning influenced Asian air mass were compared with an air mass influenced by both anthropogenic and biomass burning sources. This comparison clearly concludes about the 
external mixing of the two contributions both observed in the accumulation mode of the aerosol size distributions. The above external mixing is still visible in the refractory size distributions. The analysis of individual sub-micrometer particles from collected in situ samples demonstrates that individual pollution particles were mostly internally mixed (condensation processes during transport). Thus, the resulting aerosol particles of the Asian air mass (biomass burning plus anthropogenic contributions) are individually internally mixed, whereas the overall air mass is considered to be externally mixed. Soot-like inclusions highlight the presence of soot in the Eurasian air masses, even after more than 5 days of transport.

Acknowledgements. The authors would like to thank the French research agencies ANR, CNES, CNRS-INSU, and IPEV as well as EUFAR. Funding support from the French projects ANR Blanc SIMI 5-6 02101 Climate Impact of Short-lived Pollutants and Methane in the Arctic (CLIMSLIP) and CLIMSIP-LEFE (CNRSINSU) is acknowledge. NILU researchers were supported by the Norwegian Research Council in the framework of POLARCATNorway and CLIMSLIP. We also would like to thank SAFIRE and Christophe Gourbeyre for their support during the planning and execution of the French ATR-42 campaigns and, together with DT-INSU, for help with instrument integration.

Edited by: P. Quinn

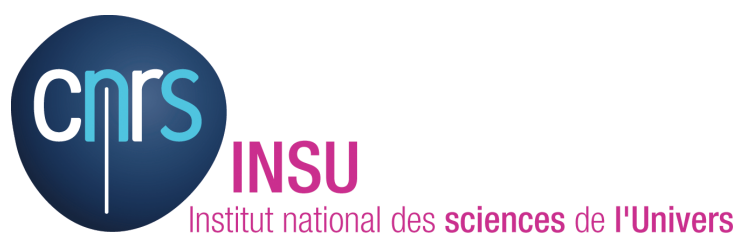

The publication of this article is financed by CNRS-INSU.

\section{References}

Adam de Villiers, R., Ancellet, G., Pelon, J., Quennehen, B., Schwarzenboeck, A., Gayet, J.-F., and Law, K. S.: Airborne measurements of aerosol optical properties related to early spring transport of mid-latitude sources into the Arctic, Atmos. Chem. Phys., 10, 5011-5030, doi:10.5194/acp-10-5011-2010, 2010.

Albrecht, B. A.: Aerosols, Cloud Microphysics, and Fractional Cloudiness, Science, 245, 1227-1230, 1989.

Andreae, M. O.: Soot carbon and excess fine potassium: Long-range transport of combustion-derived aerosols, Science, 220, 11481151, 1983.

Benton, A. K., Langridge, J. M., Ball, S. M., Bloss, W. J., Dall'Osto, M., Nemitz, E., Harrison, R. M., and Jones, R. L.: Night-time chemistry above London: measurements of $\mathrm{NO}_{3}$ and $\mathrm{N}_{2} \mathrm{O}_{5}$ from the BT tower, Atmos. Chem. Phys., 10, 9781-9795, doi:10.5194/acp-10-9781-2010, 2010.

Birmili, W., Heinke, K., Pitz, M., Matschullat, J., Wiedensohler, A., Cyrys, J., Wichmann, H.-E., and Peters, A.: Particle num- ber size distributions in urban air before and after volatilisation, Atmos. Chem. Phys., 10, 4643-4660, doi:10.5194/acp-10-46432010, 2010.

Bourgeois, Q. and Bey, I.: Pollution transport efficiency toward the Arctic: Sensitivity to aerosol scavenging and source regions, J. Geophys. Res., 116, D08213, doi:10.1029/2010JD015096, 2011.

Brock, C., Radke, L., and Hobbs, P.: Sulfur in particles in Arctic hazes derived from airborne in situ and lidar measurements, J. Geophys. Res., 95, 22369-22387, 1990.

Brock, C. A., Cozic, J., Bahreini, R., Froyd, K. D., Middlebrook, A. M., McComiskey, A., Brioude, J., Cooper, O. R., Stohl, A., Aikin, K. C., De Gouw, J. A., Fahey, D., Ferrare, R., Gao, R. S., Gore, W., Holloway, J. S., Hübler, G., Jefferson, A., Lack, D. A., Lance, S., Moore, R. H., Murphy, D. M., Nenes, A., Novelli, P. C., Nowak, J. B., Ogren, J. A., Peischl, J., Pierce, R. B., Pilewskie, P., Quinn, P. K., Ryerson, T. B., Schmidt, K. S., Schwarz, J. P., Sodemann, H., R., S. J., Stark, H., Thomson, D. S., Thornberry, T., Veres, P., Watts, L. A., Warneke, C., and Wollny, A. G.: Characteristics, sources, and transport of aerosols measured in spring 2008 during the aerosol, radiation, and cloud processes affecting Arctic Climate (ARCPAC) project, Atmos. Chem. Phys., 11, 2423-2453, doi:10.5194/acp-11-2423-2011, 2011.

Clarke, A. D., Charlson, R. J., and Radke, L. F.: Airborne observations of Arctic aerosols. IV: Optical properties of Arctic Haze, Geophys. Res. Lett., 11, 405-408, doi:10.1029/GL011i005p00405, 1984.

Dentener, F., Kinne, S., Bond, T. C., Boucher, O., Cofala, J., Generoso, S., Ginoux, P., Gong, S., Hoelzemann, J. J., Ito, A., Marelli, L., Penner, J. E., Putaud, J.-P., Textor, C., Schultz, M., van der Werf, G. R., and Wilson, J.: Emissions of primary aerosol and percursor gases in the year 2000 and 1750 prescribed data-sets for AeroCom, Atmos. Chem. Phys., 6, 43214344, doi:10.5194/acp-6-4321-2006, 2006.

Draxler, R. R. and Rolph, G. D.: HYSPLIT (HYbrid Single-Particle Lagrangian Integrated Trajectory) Model access via NOAA ARL READY Website (http://ready.arl.noaa.gov/HYSPLIT. php), NOAA Air Resources Laboratory, Silver Spring, MD, 2010.

Dreiling, V. and Friederich, B.: Spatial distribution of the arctic haze aerosol size distribution in western and eastern Arctic, Atmos. Res., 44, 133-152, doi:10.1016/S0169-8095(96)00035-X, 1997.

Fiebig, M., Stohl, A., Wendish, M., Eckhardt, S., and Petzold, A.: Dependence of solar radiative forcing of forest fire aerosol on ageing and state of mixture, Atmos. Chem. Phys., 3, 881-891, doi:10.5194/acp-3-881-2003, 2003.

Frossard, A. A., Shaw, P., Russell, L. M., Kroll, J. H., Canagaratna, M. J., Worsnop, D. R., Quinn, P. K., and Bates, T. S.: Springtime Arctic haze contributions of submicron organic particles from European and Asian combustion sources, J. Geophys. Res., 116, D05205, doi:10.1029/2010JD015178, 2011.

Fuelberg, H. E., Harrigan, D. L., and Sessions, W.: A meteorological overview of the ARCTAS 2008 mission, Atmos. Chem. Phys., 10, 817-842, doi:10.5194/acp-10-817-2010, 2010.

Garrett, T. J. and Zhao, C.: Increased Arctic cloud longwave emissivity associated with pollution from mid-latitudes, Nature, 440, 787-789, doi:10.1038/nature04636, 2006.

Giglio, L., Descloitres, J., Justice, C. O., and Kaufman, Y.: An enhanced contextual fire detection algorithm for MODIS, 
Remote Sens. Environ., 87, 273-282, doi:10.1016/S00344257(03)00184-6, 2003.

Greenaway, K. R.: Experiences with Arctic flying weather, Royal Meteorol. Soc. Can. Branch, Toronto, Ont., Canada, 1950.

Guazzotti, S. A., Suess, D. T., Coffee, K. R., Quinn, P. K., Bates, T. S., Wisthaler, A., Hansel, A., Ball, W. P., Dickerson, R. R., Neususs, C., Crutzen, P. J., and Prather, K. A.: Characterization of carbonaceous aerosols outflow from India and Arabia: Biomass/biofuel burning and fossil fuel combustion, J. Geophys. Res., 108, 4485, doi:10.1029/2002JD003277, 2003.

Häkkinen, S. A. K., Äijälä, M., Lehtipalo, K., Junninen, H., Backman, J., Virkkula, A., Nieminen, T., Vestenius, M., Hakola, H., Ehn, M., Worsnop, D. R., Kulmala, M., Petäjä, T., and Riipinen, I.: Long-term volatility measurements of submicron atmospheric aerosol in Hyytiälä, Finland, Atmos. Chem. Phys. Discuss., 12, 11201-11244, doi:10.5194/acpd-12-11201-2012, 2012.

Hallquist, M., Stewart, D. J., Baker, J., and Cox, R. A.: Hydrolysis of $\mathrm{N}_{2} \mathrm{O}_{5}$ on submicron sulfuric acid aerosols, J. Phys. Chem. A, 104, 3984-3990, 2000.

Hinds, W. C.: Aerosol technology: properties, behaviour and measurement of airborne particles, Wiley-Interscience, 1999.

Hirdman, D., Sodemann, H., Eckhardt, S., Burkhart, J. F., Jefferson, A., Mefford, T., Quinn, P. K., Sharma, S., Ström, J., and Stohl, A.: Source identification of short-lived pollutants in the Arctic using statistical analysis of measurements data and particle dispersion model output, Atmos. Chem. Phys., 10, 669-693, doi:10.5194/acp-10-669-2010, 2010.

Huang, L., Gong, S. L., Sharma, S., Lavoué, D., and Jia, C. Q.: A trajectory analysis of atmospheric transport of black carbon aerosols to Canadian high Arctic in winter and spring (19902005), Atmos. Chem. Phys., 10, 5065-5073, doi:10.5194/acp10-5065-2010, 2010.

IPCC: Climate Change 2007: Synthesis Report. Contribution of Working groups I, II and III to the fourth Assessement Report of the Intergouvernemental Panel on Climate Change, edited by: Core Writing Team, Pachauri, R. K., and Reisinger, A., IPCC, Geneva, Switzerland, 2007.

Jacobson, M. Z.: Fundamentals of atmospheric modeling, 2nd Edn., Cambridge University press, Cambridge, UK, 2005.

Janhäll, S., Andreae, M. O., and Pöschl, U.: Biomass burning aerosol emissions from vegetation fires: particle number and mass emission factors and size distributions, Atmos. Chem. Phys., 10, 1427-1439, doi:10.5194/acp-10-1427-2010, 2010.

Law, K. S. and Stohl, A.: Arctic Air Pollution: Origins and Impacts, Science, 315, 1537-1540, doi:10.1126/science.1137695, 2007.

Lubin, D. and Vogelmann, A. M.: A climatologically significant aerosol longwave indirect effect in the Arctic, Nature, 439, 453456, doi:10.1038/nature04449, 2006.

Matsuki, A., Iwasaka, Y., Shi, G. Y., Chen, H. B., Osada, K., Zhang, D., Kido, M., Inomata, Y., Kim, Y. S., Trochkine, D., Nishita, C., Yamada, M., Nagatani, M., and Nakata, H.: Heterogeneous sulfate formation on dust surface and its dependence on mineralogy: Balloon-borne measurements in the surface atmosphere of Beijing, China, Water, Air and Soil Pollution: Focus, 5, 101-132, 2005a.

Matsuki, A., Iwasaka, Y., Shi, G. Y., Zhang, D., Trochkine, D., Yamada, M., Kim, Y. S., Chen, B., Nagatani, T., Miyazawa, T., Nagatani, M., and Nakata, H.: Morphological and chemical modification of mineral dust: Observational insight into the heteroge- neous uptake of acidic gases, Geophys. Res. Lett., 32, L22806, doi:10.1029/2005GL024176, 2005b.

Matsuki, A., Quennehen, B., Schwarzenboeck, A., Crumeyrolle, S., Venzac, H., Laj, P., and Gomes, L.: Temporal and vertical variations of aerosol physical and chemical properties over West Africa: AMMA aircraft campaign in summer 2006, Atmos. Chem. Phys., 10, 8437-8451, doi:10.5194/acp-10-84372010, 2010.

McCormick, R. A. and Ludwig, H.: Climate modification by atmospheric aerosols, Science, 156, 1358-1359, 1967.

McMeeking, G. R., Hamburger, T., Liu, D., Flynn, M., Morgan, W. T., Northway, M., Highwood, E. J., Krejci, R., Allan, J. D., Minikin, A., and Coe, H.: Black carbon measurements in the boundary layer over western and northern Europe, Atmos. Chem. Phys., 10, 9393-9414, doi:10.5194/acp-10-9393-2010, 2010.

Mentel, T. F., Bleilebens, D., and Wahner, A.: A study of nighttime nitrogen oxide oxidation in a large reaction chamber - The fate of $\mathrm{NO}_{2}, \mathrm{~N}_{2} \mathrm{O}_{5}, \mathrm{HNO}_{3}$, and $\mathrm{O}_{3}$ at different humidities, Atmos. Environ., 30, 4007-4020, 1996.

Merlaud, A., Theys, N., Fayt, C., Hermans, C., Quennehen, B., Schwarzenboeck, A., Pommier, M., Ancellet, G., Burkhart, J., Stohl, A., and Van Roozendael, M.: Airborne DOAS measurements in Arctic: vertical distributions of aerosol extinction coefficient and $\mathrm{NO}_{2}$ concentration, Atmos. Chem. Phys., 11, 9219 9236, doi:10.5194/acp-11-9219-2011, 2011.

Methven, J., Arnold, S. R., Stohl, A., Evans, M. J., Avery, M., Law, K. S., Lewis, A. C., Monks, P. S., Parrish, D. D., Reeves, C. E., Schlager, H., Atlas, E., Blake, D. R., Coe, H., Crosier, J., Flocke, F. M., Holloway, J. S., Hopkins, J. R., McQuaid, J., Purvis, R., Rappenglück, B., Singh, H. B., Watson, N. M., Whalley, L. K., and Williams, P. I.: Establishing Lagrangian connections between observations within air masses crossing the Atlantic during the International Consortium for Atmospheric Research on Transport and Transformation experiment, J. Geophys. Res., 111, D23S62, doi:10.1029/2006JD007540, 2006.

Mitchell, J. M.: Visual range in the polar regions with particular reference to the Alaskan Arctic, J. Atmos. Terr. Phys. Spec., Suppl., 195-211, 1957.

Müller, D., Mattis, I., Ansmann, A., Wandinger, U., Ritter, C., and Kaiser, D.: Multiwavelength Raman lidar observations of particle growth during long-range transport of forest-fire smoke in the free troposphere, Geophys. Res. Let., 34, L05803, doi:10.1029/2006GL027936, 2007.

Nédélec, P., Cammas, J.-P., Thouret, V., Athier, G., Cousin, J.-M., Legrand, C., Abonnel, C., Lecoeur, F., Cayez, G., and Marizy, C.: An improved infrared carbon monoxide analyser for routine measurements aboard commercial Airbus aircraft: technical validation and first scientific results of the MOZAIC III programme, Atmos. Chem. Phys., 3, 1551-1564, doi:10.5194/acp-3-15512003, 2003.

Petzold, A., Weinzierl, B., Huntrieser, H., Stohl, A., Real, E., Cozic, J., Fiebig, M., Hendricks, J., Lauer, A., Law, K. S., Roiger, A., Schlager, H., and Weingartner, E.: Pertubation of the European free troposphere aerosol by North American forest fire plumes during the ICARTT-ITOP experiment in summer, Atmos. Chem. Phys., 7, 5105-5127, doi:10.5194/acp-7-5105-2007, 2007.

Pommier, M., Law, K. S., Clerbaux, C., Turquety, S., Hurtmans, D., Hadji-Lazaro, J., Coheur, P.-F., Schlager, H., Ancellet, G., Paris, J.-D., Nédélec, P., Diskin, G. S., Podolske, J. R., Holloway, 
J. S., and Bernath, P.: IASI carbon monoxide validation over the Arctic during POLARCAT spring and summer campaigns, Atmos. Chem. Phys., 10, 10655-10678, doi:10.5194/acp-1010655-2010, 2010.

Pratt, K. A. and Prather, K. A.: Real-time, single-particle volatility, size, and chemical composition measurements of aged urban aerosols, Environ. Sci. Technol., 43, 8276-8282, doi:10.1021/es902002t, 2009.

Quennehen, B., Schwarzenboeck, A., Schmale, J., Schneider, J., Sodemann, H., Stohl, A., Ancellet, G., Crumeyrolle, S., and Law, K. S.: Physical and chemical properties of pollution aerosol particles transported from North America to Greenland as measured during the POLARCAT summer campaign, Atmos. Chem. Phys., 11, 10947-10963, doi:10.5194/acp-11-10947-2011, 2011.

Quinn, P. K., Miller, T. L., Bates, T. S., Ogren, J. A., Andrews, E., and Shaw, G. E.: A three-year record of simultaneously measured aerosol chemical and optical properties at Barrow, Alaska, J. Geophys. Res., 107, 4130, doi:10.1029/2001JD001248, 2002.

Quinn, P. K., Shaw, G., Andrews, E., Dutton, E. G., RuohoAirola, T., and Gong, S. L.: Arctic Haze: Current trend and knowledge gaps, Tellus B, 59, 99-114, doi:10.1111/j.16000889.2006.00238.x, 2007.

Reid, J. S. and Hobbs, P. V.: Physical and optical properties of young smoke from individual biomass fires in Brazil, J. Geophys. Res., 103, 32013-32030, 1998.

Reid, J. S., Hobbs, P. V., Ferek, R. J., Blake, D. R., Martins, J. V., Dunlap, M. R., and Liousse, C.: Physical, chemical and optical properties of regional hazes dominated by smoke in Brazil, J. Geophys. Res., 103, 32059-32080, 1998.

Reid, J. S., Koppman, R., Eck, T. F., and Eleuterio, D. P.: A review of biomass burning part II: intensive physical properties of biomass burning particles, Atmos. Chem. Phys., 5, 827-849, doi:10.5194/acp-5-827-2005, 2005.

Riemer, N., Vogel, H., and Vogel, B.: Soot aging time scales in polluted regions during day and night, Atmos. Chem. Phys., 4, 1885-1893, doi:10.5194/acp-4-1885-2004, 2004.

Roiger, A., Schlager, H., Schälfer, A., Huntriesser, H., Scheibe, M., Aufmhoff, H., Cooper, O. R., Sodemann, H., Stohl, A., Burkhart, J., Lazzara, M., Schiller, C., Law, K. S., and Arnold, F.: Insitu observation of Asian pollution transported into the Arctic lowermost stratosphere, Atmos. Chem. Phys., 11, 10975-10994, doi:10.5194/acp-11-10975-2011, 2011.

Rolph, G. D.: Real-time Environmental Applications and Display sYstem (READY) Website (http://ready.arl.noaa.gov), NOAA Air Resources Laboratory, Silver Spring, MD, 2010.

Schmale, J., Schneider, J., Ancellet, G., Quennehen, B., Stohl, A., Sodemann, H., Burkhart, J. F., Hamburger, T., Arnold, S. R., Schwarzenboeck, A., Borrmann, S., and Law, K. S.: Source identification and airborne chemical characterisation of aerosol pollution from long-range transport over Greenland during POLARCAT summer campaign 2008, Atmos. Chem. Phys., 11, 1009710123, doi:10.5194/acp-11-10097-2011, 2011.
Schnell, R. C.: Arctic haze and the Arctic Gas and Aerosol Sampling Program (AGASP), Geophys. Res. Lett., 11, 361-364, doi:10.1029/GL011i005p00361, 1984.

Schwarzenboeck, A., Heintzenberg, J., and Mertes, M.: Incorporation of aerosol particles between 25 and $850 \mathrm{~nm}$ into cloud element: measurements with a new complementary sampling system, Atmos. Res., 52, 241-260, 2000.

Seinfeld, J. H. and Pandis, S. N.: Atmospheric chemistry \& physics, John Wiley \& Sons, New York, 1998.

Sharma, S., Brook, J. R., Cachier, H., Chow, J., Gaudenzi, A., and Lu, G.: Light absorption and thermal measurements of black carbon in different regions of Canada, J. Geophys. Res., 107, 4771, doi:10.1029/2002JD002496, 2002.

Sharma, S., Lavoué, D., Cachier, H., Barrie, L. A., and Gong, S. L.: Long-term trends of black carbon concentrations in the Canadian Arctic, J. Geophys. Res., 109, D15203, doi:10.1029/2003JD004331, 2004.

Sharma, S., Andrews, E., Barrie, L. A., Ogren, J. A., and Lavoué, D.: Variations and sources of the equivalent black carbon in the high Arctic revealed by long-term observations at Alert and Barrow 1989-2003, J. Geophys. Res., 111, D14208, doi:10.1029/2005JD006581, 2006.

Stohl, A.: Characteristics of atmospheric transport into the Arctic troposphere, J. Geophys. Res., 111, 0148-0227, doi:10.1029/2005JD006888, 2006.

Stohl, A., Hittenberger, M., and Wotawa, G.: Validation of the lagrangian particle dispersion model FLEXPART against largescale tracer experiment data, Atmos. Environ., 32, 4245-4264, doi:10.1016/S1352-2310(98)00184-8, 1998.

Stohl, A., Forster, C., Eckhardt, S., Spichtinger, N., Huntrieser, H., Heland, J., Schlager, H., Wilhelm, F., Arnold, F., and Cooper, O.: A backward modeling study of intercontinental pollution transport using aircraft measurements, J. Geophys. Res., 108, 4370, doi:10.1029/2002JD002862, 2003.

Stohl, A., Forster, C., Frank, A., Seibert, P., and Wotawa, G.: Technical note: The Lagrangian particle dispersion model FLEXPART version 6.2, Atmos. Chem. Phys., 5, 2461-2474, doi:10.5194/acp-5-2461-2005, 2005

Twomey, S.: The Influence of Pollution on the Shortwave Albedo of Clouds, J. Atmos. Sci., 34, 1149-1152, doi:10.1175/15200469(1977)034<1149:TIOPOT>2.0.CO;2, 1977.

Villani, P., Picard, D., Michaud, V., Laj, P., and Wiedensohler, A.: Design and Validation of a Volatility Hygroscopic Tandem Differential Mobility Analyzer (VH-TDMA) to Characterize the Relationships Between the Thermal and Hygroscopic Properties of Atmospheric Aerosol Particles, Aerosol Sci. Technol., 42, 729741, 2008. 